OPEN ACCESS

Edited by:

David M. Paterson, University of St Andrews,

United Kingdom

Reviewed by:

Akkur Vasudevan Raman,

Andhra University, India

Punyasloke Bhadury,

Indian Institute of Science Education and Research Kolkata, India

*Correspondence:

Sara Haro sara.haro@uca.es

Specialty section: This article was submitted to Marine Ecosystem Ecology, a section of the journal Frontiers in Marine Science

Received: 25 July 2019 Accepted: 21 January 2020

Published: 14 February 2020

Citation:

Haro S, Lara M, Laiz I, González CJ, Bohórquez J, Garcia-Robledo E, Corzo A and Papaspyrou S (2020) Microbenthic

Net Metabolism Along Intertidal Gradients (Cadiz Bay, SW Spain):

Spatio-Temporal Patterns

and Environmental Factors.

Front. Mar. Sci. 7:39

doi: 10.3389/fmars.2020.00039

\section{Microbenthic Net Metabolism Along Intertidal Gradients (Cadiz Bay, SW Spain): Spatio-Temporal Patterns and Environmental Factors}

\author{
Sara Haro ${ }^{1 *}$, Miguel Lara1, Irene Laiz², Carlos José González³, Julio Bohórquez", \\ Emilio Garcia-Robledo ${ }^{1}$, Alfonso Corzo ${ }^{1}$ and Sokratis Papaspyrou ${ }^{1}$
}

\begin{abstract}
${ }^{1}$ Department of Biology, Faculty of Marine and Environmental Sciences, University of Cádiz, Cádiz, Spain, ${ }^{2}$ Department of Applied Physics, University of Cádiz, Cádiz, Spain, ${ }^{3}$ Division of Naval Support and Oceanography, Marine Hydrographic Institute, Spanish Navy, Cádiz, Spain
\end{abstract}

Microphytobenthos (MPB), the photosynthetic primary producing component of microbenthos, shows variable patterns in its biomass distribution along the intertidal gradient as a result of the interactions of factors such as light, tides, temperature, and grazing pressure. These patterns have been studied more extensively in northern European estuaries than southern European coastal systems. Even less information is available regarding temporal changes in MPB primary production rates in these systems. For this reason, we followed the seasonal changes in net production in light and dark respiration rates (determined by oxygen microelectrodes) and MPB biomass (estimated by sediment chlorophyll a) along the intertidal gradient of the inner Cadiz Bay during a year. Sediment cores were collected along two transects (five sampling stations per transect) with distinct sediment granulometry: one muddy [Puerto Real (PR)] and one muddy-sandy transect [San Fernando (SF)]. Our results show that MPB biomass and net production increased seawards reaching their maxima in winter. In contrast to what is observed in northern European systems, the higher solar irradiance and temperatures occurring in summer in southern Spain likely inhibit MPB production. In Cadiz Bay, spatial patterns of MPB biomass and net production depended on season and location due to the environmental heterogeneity observed. Environmental variables, analyzed by principal component analysis (PCA), were used to explain the variability of MPB metabolism by multiple regression. Selected principal component (PC) axes explained $60 \%$ of the net production in light and $41 \%$ of the dark respiration rates variability in PR, while they only accounted for $25 \%$ of the same rates in SF. The differences observed between transects and the variability in the environmental variables explaining them highlight the importance of considering the spatial heterogeneity of our system to estimate the contribution of MPB to the inner Cadiz Bay productivity. In our case, this contribution is significant accounting for up to $49 \%$ of the total benthic production of the inner Cadiz Bay intertidal sediments, confirming previous global estimates.

Keywords: microphytobenthos, primary production, metabolism, intertidal sediment, oxygen microelectrodes, chlorophyll 


\section{INTRODUCTION}

Microphytobenthos (MPB), the photosynthetic community inhabiting the surface layer of euphotic sediments, plays a key role in the cycling of carbon and nitrogen in estuaries and other coastal shallow ecosystems, being able to contribute up to $50 \%$ of their total primary production (Underwood and Kromkamp, 1999). However, patterns of MPB biomass distribution and primary production vary strongly in estuarine ecosystems as a result of the high variability and interactions of environmental factors which characterizes these systems (Benyoucef et al., 2013). Among these factors, irradiance and temperature are the ones considered to most strongly affect MPB photosynthetic rates (Hancke and Glud, 2004; Migné et al., 2004; Davoult et al., 2009). In addition, a large number of other variables have been used to explain variations in MPB abundance and composition in time and space. Some of them include sediment type, tidal height, sediment desiccation and compaction, grazing pressure, salinity, topography, and nutrients availability both in the sediment porewater and the water column (Coelho et al., 2009; Jesus et al., 2009; Pratt et al., 2015; Garcia-Robledo et al., 2016).

The majority of studies focusing on the distribution of MPB biomass at the sediment surface have been performed using the pulse amplitude modulation (PAM) technique, spectral reflectance analysis, or remote sensing (Jesus et al., 2005; Murphy et al., 2008; Benyoucef et al., 2013). However, these methods do not measure directly microphytobenthic primary production $\left(\mathrm{PP}_{\mathrm{MPB}}\right)$ or respiration. To quantify these processes, methods such as benthic chamber or whole core incubations, ${ }^{14} \mathrm{C}$ incorporation, or oxygen microsensor measurements are required. However, these methods are difficult to upscale in order to monitor intertidal areas at a large scale. As a result, little is known on the distribution of MPB primary production, respiration, and net metabolism rates at large spatial and temporal scales. Despite this shortcoming, oxygen microelectrodes have been used to determine the distribution of MPB production rates in time and space, showing good agreement with ${ }^{14} \mathrm{C}$ incubations data (Revsbech et al., 1981; Barranguet et al., 1998). Oxygen measurements are then usually upscaled to larger areas using several models of $\mathrm{PP}_{\mathrm{MPB}}$ developed for the purpose (Pinckney and Zingmark, 1993; Serôdio and Catarino, 2000). Regardless of the method used, seasonal and spatial patterns of $\mathrm{PP}_{\mathrm{MPB}}$, similarly to MPB biomass, have been explained by a wide array of biotic and abiotic environmental variables depending on the environment studied (Hubas et al., 2006; Jesus et al., 2009; Orvain et al., 2012; Savelli et al., 2018).

Fluctuations in environmental variables result in MPB biomass changes on temporal scales ranging from days to seasons (Migné et al., 2004; Serôdio et al., 2005). MPB seasonal patterns seem to differ between northern and southern European estuaries. In northern Europe, the maximum of MPB biomass is observed in summer, whereas in southern Europe, in most cases, the maximum is found in winter and early spring (Van der Wal et al., 2010; Benyoucef et al., 2013; Brito et al., 2013; Garcia-Robledo et al., 2016; Savelli et al., 2018). Seasonal patterns with maximum values of MPB biomass in winter have also been reported at latitudes similar to those of southern Europe, in
Korea and Japan (Goto et al., 2000; Koh et al., 2007; Kwon et al., 2016). In fact, intertidal MPB can adapt physiologically to a combined light-temperature stress gradient, such as that found along the Atlantic coast of southern Europe (Laviale et al., 2015). Therefore, latitudinal conditions of light and temperature seem to be important factors affecting seasonal and spatial patterns of MPB distribution.

The spatial distribution of MPB biomass ranges from centimeters to kilometers depending on the system (Guarini et al., 1998; Maggi et al., 2017). Along the intertidal gradient, the maximum MPB biomass is usually found at the high shore with biomass decreasing seawards. This pattern has been observed in both southern (Orvain et al., 2012; Brito et al., 2013; Maggi et al., 2017) and northern European estuaries (Van der Wal et al., 2010; Benyoucef et al., 2013), and is attributed to a higher irradiance dose in the upper shore (i.e., due to a shallower water column and a longer emersion period). However, in some southern European estuaries, the long emersion period in the upper shore produces greater sediment desiccation and exposure to extreme temperatures, inverting the trend described (Coelho et al., 2009; Laviale et al., 2015).

In the present study, we wanted to test two hypotheses: (1) annual maxima in biomass and primary production occur during the winter months at lower latitude temperate intertidal flats, in contrast to what has been generally observed at higher latitudes, and (2) higher biomass and net primary production occur at the upper shore, most likely due to a higher daily irradiance dose as a result of a lower light attenuation by the water column in comparison to the lower intertidal range. To test these hypotheses, we studied the seasonal distribution of MPB biomass and net metabolism (net production in light and dark respiration) along the intertidal gradient in the inner Cadiz Bay (Spain, southern Europe). In addition, we tried to identify environmental variables that could explain the variation in MPB net metabolism in the bay, both seasonally and in space, by multivariate and multiple regression analyses.

\section{MATERIALS AND METHODS}

\section{Study Site and Sampling}

The inner Cadiz Bay is a shallow water body, with an average depth of less than $3 \mathrm{~m}$. The intertidal zone (maximum length $9.3 \mathrm{~km}$; width $5.25 \mathrm{~km}$ ) covers $\sim 60 \%$ of its surface. Sediment is predominantly mud (size grain $<63 \mu \mathrm{m}$ ) (Sanchez De Lamadrid Rey and Muñoz Pérez, 1994; Carrasco et al., 2003). The bay is affected by semidiurnal tides that oscillate between a maximum tidal height of $1.75 \mathrm{~m}$ and a minimum of $-1.5 \mathrm{~m}$ relative to the local mean sea level (MSL). Circulation is mainly controlled by tides, which is the main mechanism of water renovation. Strong easterly winds are frequent in the region and contribute to sediment resuspension (Gutiérrez et al., 2000; Ligero et al., 2005). Submerged vegetation changes along the intertidal gradient, mainly in locations with a high variability in sediment grain size along the intertidal zone (Morris et al., 2009; Lara et al., 2016) (Figure 1). In the inner Cadiz Bay, $70 \%$ of the intertidal area is covered by Zostera noltei meadows, $20 \%$ is bare sediment, 

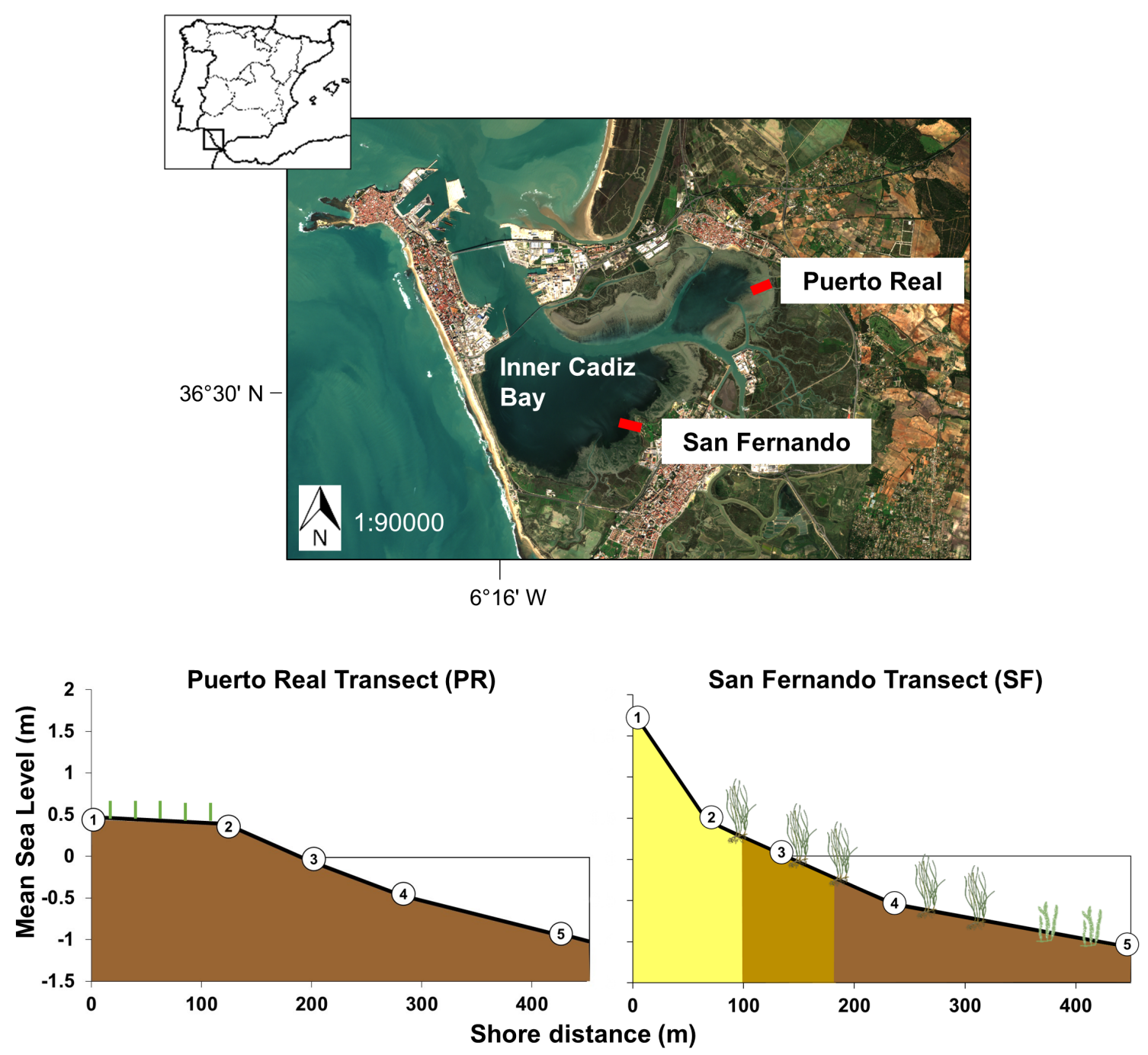

Vegetation type

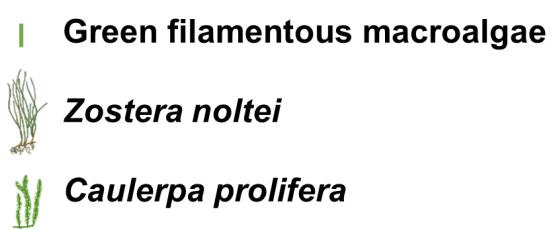

$\%$ grain size $<63 \mu \mathrm{m}$

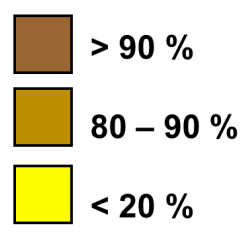

FIGURE 1 | Map of inner Cadiz Bay indicating the two studied transects: Puerto Real (PR) and San Fernando (SF). The lower panels indicate the slope profiles of each transect and the sampling stations as a function of shore distance (axis $x$ ) and mean sea level (axis $y$ ). The approximate distribution of grain size distribution $(<63 \mu \mathrm{m})$ and vegetation species zonation are indicated.

occasionally covered in parts by green macroalgae, whereas the remaining $10 \%$ is shared between Caulerpa prolifera and Cymodocea nodosa meadows, which inhabit the lower fringe of the intertidal zone (Gómez Ordoñez, 2008; Brun et al., 2015). MPB community studies do not exist for the inner bay; however, published experimental data using sediment from the wider bay area indicate a dominance of diatoms which is disturbed in the presence of green macroalgal blooms in favor of cyanobacteria (Garcia-Robledo et al., 2008, 2012; Haro et al., 2019). Preliminary semi-quantitative data for the inner bay sediments based on molecular analyses indicate the presence of both diatoms and cyanobacteria throughout the intertidal area (J. Taylor pers. comm). Cyanobacteria show higher relative abundances (within prokaryotes) in the upper intertidal, especially in sandier 
sediments. The most abundant genera include Pleurocapsa sp., Phormidium sp., and Rivularia sp. in sandy muddy sediments and Lyngbya sp. and Coleofasciculus sp. in muddy sediments. Diatoms also show higher relative abundance in the upper intertidal (within eukaryotic OTUs). Most common genera include Amphora sp., Navicula sp., Nitzschia sp., Pleurosigma sp., and Placoneis sp. in sandy muddy sediments and Skeletonema sp., Gyrosigma sp., and Navicula sp. in muddy sediments. A more detailed description of the sampling area can be found in Papaspyrou et al. (2013) and Jimenez-Arias et al. (2016).

Samplings were performed along two transects in the inner Cadiz Bay, each $500 \mathrm{~m}$ long, once per season (July and October 2016, and January and April 2017) (Figure 1). The two transects were selected to include the range of grain size distributions found in the area. In Puerto Real (PR), sediment is mainly mud, whereas in San Fernando (SF) a mixture of sand and mud. Five stations were distributed along each transect to cover from the upper intertidal (1.7 $\mathrm{m}$ above MSL in SF and $0.5 \mathrm{~m}$ in $\mathrm{PR})$ to the lower intertidal $(-1.5 \mathrm{~m}$ below MSL in both cases) (Supplementary Table 1). Samplings were performed during spring tides (average tidal coefficient of $\sim 80$ ), at high tide to ensure access by rowboat along the entire transect. Samplings took place during the same week for both transects, 1 day per transect.

At each sampling station, six sediment cores (i.d. $5.2 \mathrm{~cm}$; $27 \mathrm{~cm}$ length) were collected using a Kajak sediment sampler (model 13.030, KC, Denmark). Water column samples were also collected at each station. Cores and water samples were kept on ice until returning to the laboratory. Upon arrival to the laboratory, water column samples were immediately filtered through a GF/F filter and stored frozen $\left(-20^{\circ} \mathrm{C}\right)$ until nutrient analyses. Sediment cores were placed in an aquarium connected to a tank filled with in situ seawater under constant temperature $\left(18^{\circ} \mathrm{C}\right)$. The aquarium was illuminated with fluorescent lamps (Lumina 1080 Blau Aquaristic) at $200 \mu \mathrm{mol}$ photon $\mathrm{m}^{-2} \mathrm{~s}^{-1}$ under a $12 \mathrm{~h}$ light: $12 \mathrm{~h}$ dark photoperiod. Three cores were sliced on the same day (upper $0.5 \mathrm{~cm}$ ), the sediment centrifuged at $4700 \times \mathrm{g}$ for $20 \mathrm{~min}$ at $4^{\circ} \mathrm{C}$, and the supernatant preserved at $-20^{\circ} \mathrm{C}$ for porewater analysis.

\section{Microsensor Measurements}

Oxygen microprofiles were measured in each of three cores, in light and in darkness, using $\mathrm{O}_{2}$ microelectrodes $(50 \mu \mathrm{m}$ tip size, Unisense A/S, Denmark). In order to obtain the maximum potential primary production rates, $\mathrm{O}_{2}$ microprofiles in light were measured after 30 min under a saturating irradiance $(1200 \mu \mathrm{mol}$ photon $\left.\mathrm{m}^{-2} \mathrm{~s}^{-1}\right)$. Dark respiration rates $\left(\mathrm{R}_{\mathrm{D}}\right)$ and net production of the photosynthetic layer in light $\left(\mathrm{P}_{\mathrm{N}}\right)$ were determined from the oxygen vertical profiles by applying Fick's first law (Revsbech and Jorgensen, 1983; Kühl et al., 1996). The oxygen diffusion coefficient was obtained from standard values for the prevailing conditions of salinity and temperature (Soetaert et al., 2010), and corrected for sediment tortuosity (Li and Gregory, 1974). Microprofiles were performed in areas within sediment cores where no macrophytes or macroalgae were present. In the few cases where macrophytes were abundant in sediment cores, they were carefully removed without disturbing the sediment surface, and microprofiles were measured only within clear bare sediment zones.

\section{Sediment Variables}

Once oxygen microprofiles were measured, the upper $0.5 \mathrm{~cm}$ sediment layer was obtained. A portion of fresh sediment $(\sim 5 \mathrm{~g})$ was used to determine sediment density as the weight of a known volume. Porosity was determined as the loss of water of a known volume of sediment sample after drying at $60^{\circ} \mathrm{C}$ for $72 \mathrm{~h}$. The percentage of fines $(<63 \mu \mathrm{m})$ was determined by wet sieving after removing organic matter with hydrogen peroxide $\left(\mathrm{H}_{2} \mathrm{O}_{2}\right)$ and dispersing the sediment with sodium hexametaphosphate $\left(\mathrm{NaPO}_{3}\right)_{6}$ (Buchanan, 1984).

Pigments' content in the sediment was measured by extraction of $\sim 2 \mathrm{~g}$ of fresh sediment in 100\% methanol buffered with $\mathrm{MgCO}_{3}$, for $12 \mathrm{~h}$ at $4^{\circ} \mathrm{C}$ in darkness (Thompson et al., 1999). Samples were centrifuged at $4700 \times g$ for $10 \mathrm{~min}$ (Sorvall Legend X1R; Thermo Scientific). Spectra of the extracts were obtained on a microplate reader (Multiskan GO; Thermo Scientific) before and after acidifying the methanol extract with $2 \mathrm{~N}$ hydrochloric acid in order to determine phaeopigments (pheo) content. Chl $a$ and $\mathrm{Chl} c$, and pheo were estimated according to Ritchie (2008) and Stal et al. (1984), respectively.

The remaining sediment was dried at $60^{\circ} \mathrm{C}$ for $72 \mathrm{~h}$. One portion of the sediment $(\sim 0.5 \mathrm{~g})$ was used to determine the organic matter content by loss on ignition (Heiri et al., 2001). Total carbon and total nitrogen (TN) contents were determined in dried sediment samples. Organic carbon (OC) was determined as the difference between total carbon measured in dried sediment samples and inorganic carbon measured on a second replicate combusted previously at $550^{\circ} \mathrm{C}$ for $5 \mathrm{~h}$. Both samples were analyzed on an elemental analyzer (LECO CHNS 932) at the Central Services of the University of A Coruña.

Sediment porewater and water column nutrient concentrations $\left[\mathrm{NH}_{4}{ }^{+}, \mathrm{NO}_{2}{ }^{-}, \mathrm{NO}_{3}{ }^{-}, \mathrm{PO}_{4}{ }^{3-}\right.$ and $\mathrm{Si}(\mathrm{OH})_{4}$, hereafter referred to as dissolved silica, DSi] were measured following standard protocols (Grasshoff et al., 1999; GarciaRobledo et al., 2014) on a microplate reader (Multiskan GO; Thermo Scientific).

\section{Physical Variables}

Mean sea level of every sampling point was computed with an independent mesh of data which combines the nautical charts 443A and 443B from the Marine Hydrographic Institute (IHM, Spain) with further topobathymetric measurements for certain localities (Tejedor et al., 1997). The value of MSL for a specific $X Y$ coordinate was approached by nearest neighbor criteria to the existing mesh. Euclidean distances to the reference nodes were calculated with the R package "geosphere" (Hijmans et al., 2017). This procedure allows to obtain the MSL of sampling points with a horizontal precision always higher than $28 \mathrm{~m}$ (i.e., assuming the worst scenario, with the point placed at the same distance from the four nodes), which is negligible due to the flat morphometry of Cadiz Bay. Longitudinal distances within the transects were calculated taking as a reference the station nearest to the shore (Figure 1). 
Meteorological conditions (irradiance, temperature, rain, and wind speed) were obtained by the Junta de Andalucía meteorological station located in El Puerto de Santa María. Values were averaged for the week before each sampling (Supplementary Figure 1).

\section{Annual Net Metabolism of the Microbenthic Intertidal Sediment}

In order to estimate the contribution of MPB communities to the annual net metabolism of the intertidal zone of the inner Cádiz Bay, we used the $\mathrm{P}_{\mathrm{N}}$ and $\mathrm{R}_{\mathrm{D}}$ rates data obtained in the different sediment types (e.g., bare muddy sediment, bare sandy sediment, seagrass meadow sediment). Daily rates of $\mathrm{P}_{\mathrm{N}}$ in light or $\mathrm{R}_{\mathrm{D}}$ in darkness were obtained by multiplying with the hours of daylight or darkness, respectively. $\mathrm{P}_{\mathrm{N}}$ rates were corrected for the variability in rates observed during daylight. To do this, given that measurements in the lab were always performed during the maximum daylight production phase, a diel correction factor was applied to account for the lower $\mathrm{P}_{\mathrm{N}}$ rates at the beginning and end of the daylight phase ( $0.67 \pm 0.3, n=4$, Haro et al., 2019). $R_{D}$ rates were considered constant during the night (Haro et al., 2019). Daily $\mathrm{P}_{\mathrm{N}}$ or $\mathrm{R}_{\mathrm{D}}$ were assumed constant during each season and were corrected for temperature differences using a $\mathrm{Q}_{10}$ of 1.56 for $\mathrm{P}_{\mathrm{N}}$ (Kwon et al., 2018) and 2.0 for $\mathrm{R}_{\mathrm{D}}$ (Grant, 1986; Hancke and Glud, 2004). To compare the obtained data with the literature, rates in $\mathrm{mmol} \mathrm{O}_{2} \mathrm{~m}^{-2}$ year ${ }^{-1}$ were converted to mmol $\mathrm{C} \mathrm{m}^{-2}$ year ${ }^{-1}$, assuming a photosynthetic quotient $1.2 \mathrm{mmol} \mathrm{O}_{2}$ : mmol $\mathrm{C}$ and a respiratory quotient $106 \mathrm{mmol}$ $\mathrm{O}_{2}$ : $138 \mathrm{mmol} \mathrm{C}$, and expressed in g C (Hedges et al., 2002). Finally, the annual net metabolism of the microbenthic intertidal sediment was calculated as the difference between the annual rates of $\mathrm{P}_{\mathrm{N}}$ in light and $\mathrm{R}_{\mathrm{D}}$ in darkness and multiplied by the surface cover of each habitat type in the intertidal area of the inner Cadiz Bay.

\section{Statistical Analysis}

In order to explore potential relationships, reduce the number of explanatory variables, and avoid collinearity effects in further analysis, a principal component analysis (PCA) was applied to the entire set of normalized environmental data (i.e., shore distance, MSL, \% grain size $<63 \mu \mathrm{m}$, irradiance, air temperature, rainfall, wind speed, porosity, salinity, OC, TN, nutrients in the water column and porewater). Chl $a, \mathrm{Chl} c$, and nutrients in porewater were log-transformed prior to analysis. Then, a multiple linear regression (MLR) model was applied using $\mathrm{P}_{\mathrm{N}}$ or $\mathrm{R}_{\mathrm{D}}$ as dependent variables and principal components (PCs) obtained from the PCA as explanatory ones (Cho et al., 2009; Lee et al., 2015). Given the biotic nature of chlorophyll and the direct link to MPB production, chlorophylls were maintained as independent variables and were not included in the initial PCA. Only PCs with eigenvalues higher than 1 were selected for MLR analysis (Jackson, 1993). Best Model variable selection procedures were employed to identify the best empirical equation of $\mathrm{P}_{\mathrm{N}}, \mathrm{R}_{\mathrm{D}}$, and MPB biomass (Zuur and Ieno, 2016). Analyses were carried out independently for each transect, due to their different nature in terms of granulometry and environmental features, as the contrasting results obtained by PCA corroborated. All statistical analysis was carried out using XLSTAT 2018 (Microsoft Office 2016).

\section{RESULTS}

\section{Abiotic Environmental Variables}

Sediment along the intertidal transects studied was mainly muddy-silt with the fine fraction $(<63 \mu \mathrm{m})$ accounting for $>90 \%$ (Supplementary Table 2), with the exception of the two upper intertidal stations in SF, where $<20 \%$ was fine sediment. A macrophytes species zonation was observed along the SF transect (Figure 1); Z. noltei was present in stations SF2SF4, whereas dense C. prolifera canopies dominated in SF5. In PR, sediment was covered by a visible brown diatomaceous biofilm year round, although more intensely in winter. Green filamentous macroalgae were also observed in the upper shore in January.

Temperature showed the typical pattern for temperate systems with higher values in July $\left(23.8 \pm 1.7^{\circ} \mathrm{C}\right)$ and lower in January $\left(10.1 \pm 1.6^{\circ} \mathrm{C}\right)$ (Supplementary Figure 1). Rainfall was minimal during the days previous to the sampling with only $0.15 \pm 0.3 \mathrm{~mm}$ registered the week before the autumn sampling. In spring, sampling occurred 1 week after a strong wind and slight rainfall event (Supplementary Figure 1).

\section{Water Column and Porewater Nutrients}

Water column nutrient concentrations were higher in general in PR than SF (Figure 2A). A clear decrease in DSi concentrations was observed seawards, less evident in PR. Water column $\mathrm{PO}_{4}{ }^{3-}$ concentrations were mostly lower than $1 \mu \mathrm{M}$ and showed a parallel trend to that of DSi. On the other hand, $\mathrm{NO}_{3}{ }^{-}$and $\mathrm{NH}_{4}{ }^{+}$concentrations showed little variation in both transects, with relatively higher values observed in PR4 (7.9 \pm 0.5 and $5.0 \pm 0.4 \mu \mathrm{M}$, respectively). Overall, $\mathrm{NO}_{3}^{-}$was slightly more abundant than $\mathrm{NH}_{4}{ }^{+}$in $\mathrm{PR}$ (Figure 2A), while $\mathrm{NO}_{2}{ }^{-}$ concentrations were below detection limits in both transects (data no shown).

In contrast to the water column, the highest concentrations of nutrients in the porewater were measured in SF (Figure 2B). Furthermore, a reverse trend to that of the water column was observed, with concentrations increasing toward lower intertidal stations. This trend was less evident in PR than in SF for almost all of the studied nutrients due to the higher concentrations found in the upper shore station. In contrast to water column, $\mathrm{NH}_{4}{ }^{+}$was the most available form of inorganic nitrogen in the porewater.

\section{Organic Carbon, Total Nitrogen, and Pigments}

Organic carbon and TN contents were always higher at the sampling stations with sediment comprising of $>90 \%$ fine particles. Thus, in PR, OC content did not vary with MSL $(\sim 3.5 \%)$, whereas in SF, it ranged from $4-5 \%$ in the muddy stations to less than $1 \%$ in the sandy stations (SF1 and SF2) (Figure 3A). TN content followed the same pattern as OC (Figure 3B). No temporal trends were observed for either OC or 

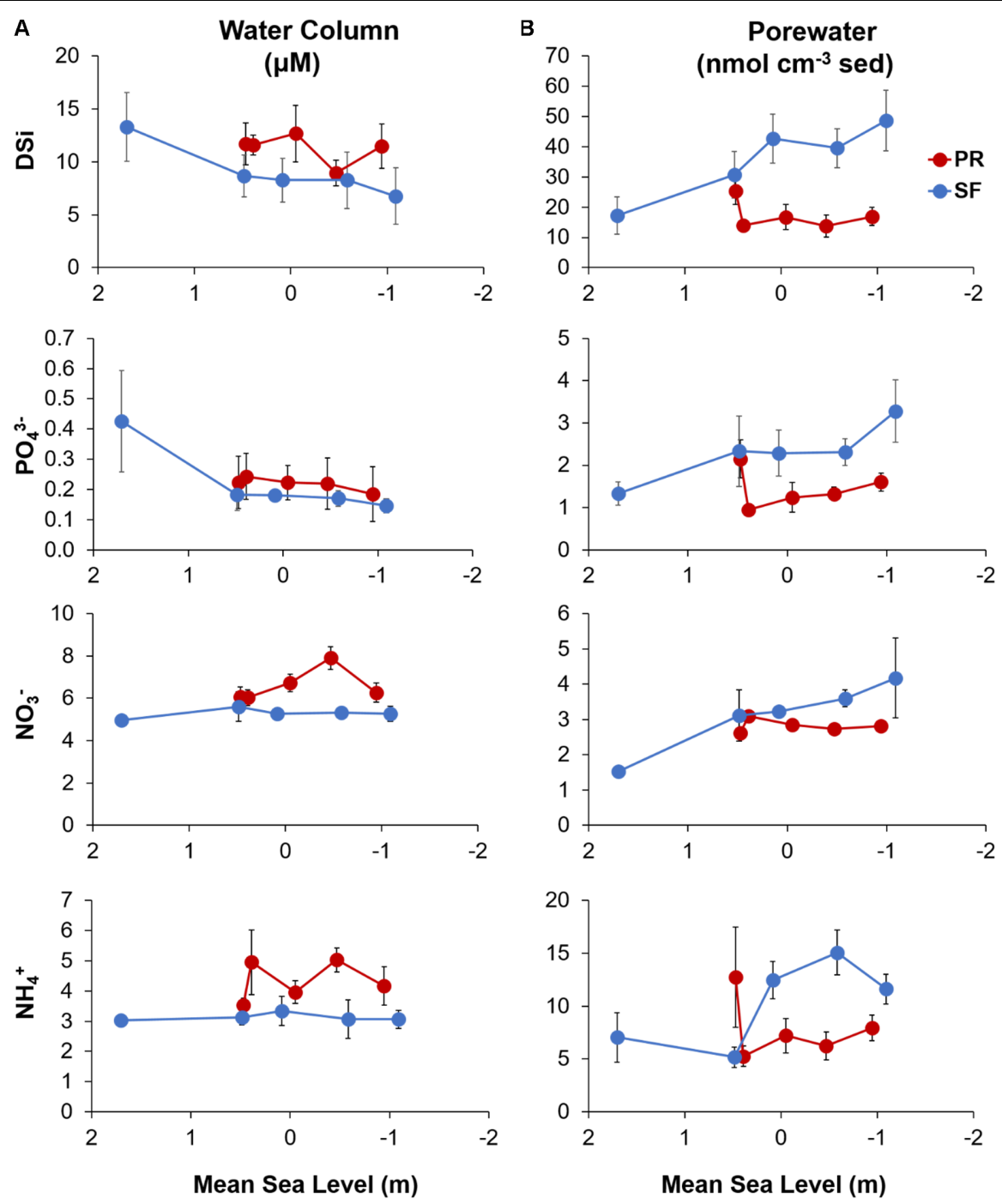

FIGURE 2 | Seasonal mean nutrients concentrations ( $\mathrm{DSi}, \mathrm{NO}_{3}{ }^{-}, \mathrm{NH}_{4}{ }^{+}$, and $\mathrm{PO}_{4}{ }^{3-}$ ) $\mathbf{( A )}$ in the water column and (B) the porewater plotted against mean sea level for the Puerto Real (PR; in red) and San Fernando (SF; in blue) transects. Water column and porewater values represent the mean \pm SE $(n=4)$.

TN content. The OC to TN ratio (Figure 3C) was also constant along the transects in both PR $(17.1 \pm 0.4)$ and SF (13.5 \pm 0.3$)$, with the exception of station SF1, where a strong temporal variability was observed.

Microphytobenthos biomass was generally higher in SF than in PR (Figure 4A). The highest Chl $a$ content was observed in both transects in January. In SF, Chl a content was threefold higher in January than in April. Distribution of MPB biomass between stations was more homogeneous in PR (average of $1.5 \mu \mathrm{g}$ chl $a \mathrm{~cm}^{-2}$ ) than in SF where values ranged between 0.6 and $6.13 \mu \mathrm{g} \mathrm{chl} a \mathrm{~cm}^{-2}$. In SF, the highest $\mathrm{Chl} a$ content was measured at stations SF3 and SF4. In PR, higher Chl $a$ values were measured in the upper intertidal, whereas the opposite was true in January.

The Chl $c$ to $\mathrm{Chl} a$ ratio showed high spatial variability in both transects (Figure 4B), with the lowest ratio observed at the lower intertidal level. In PR, the highest $\mathrm{Chl} c$ to $\mathrm{Chl} a$ ratio was found in January. In SF, differences between seasons were less evident. The pheo to Chl $a$ ratio showed a larger spatial variability in SF (range between 1.38 and 0.07 ), whereas in PR, this ratio was relatively constant along the transect (average of 0.58) (Figure 4C). OC to $\mathrm{Chl} a$ ratio did not show clear trends along the transects, although in SF it increased slightly seawards, being up to three times higher in SF5 than in SF1 in April and October (Figure 4D).

\section{Seasonal and Spatial Variability of MPB Net Metabolism}

On average, $\mathrm{P}_{\mathrm{N}}$ was higher in $\mathrm{PR}\left(4.0 \pm 0.5 \mathrm{mmol} \mathrm{O} \mathrm{m}^{-2} \mathrm{~h}^{-1}\right)$ than in $\mathrm{SF}\left(1.7 \pm 0.4 \mathrm{mmol} \mathrm{O}_{2} \mathrm{~m}^{-2} \mathrm{~h}^{-1}\right)$ (Figure 5A). Rates of $\mathrm{P}_{\mathrm{N}}$ in $\mathrm{PR}$ were much higher in January than during the rest of the seasons, increasing near the lower intertidal level. However, in April and October, although rates varied little along the intertidal, the highest $\mathrm{P}_{\mathrm{N}}$ rates were measured at PR1. In contrast, spatial variability in SF was high, with a general 


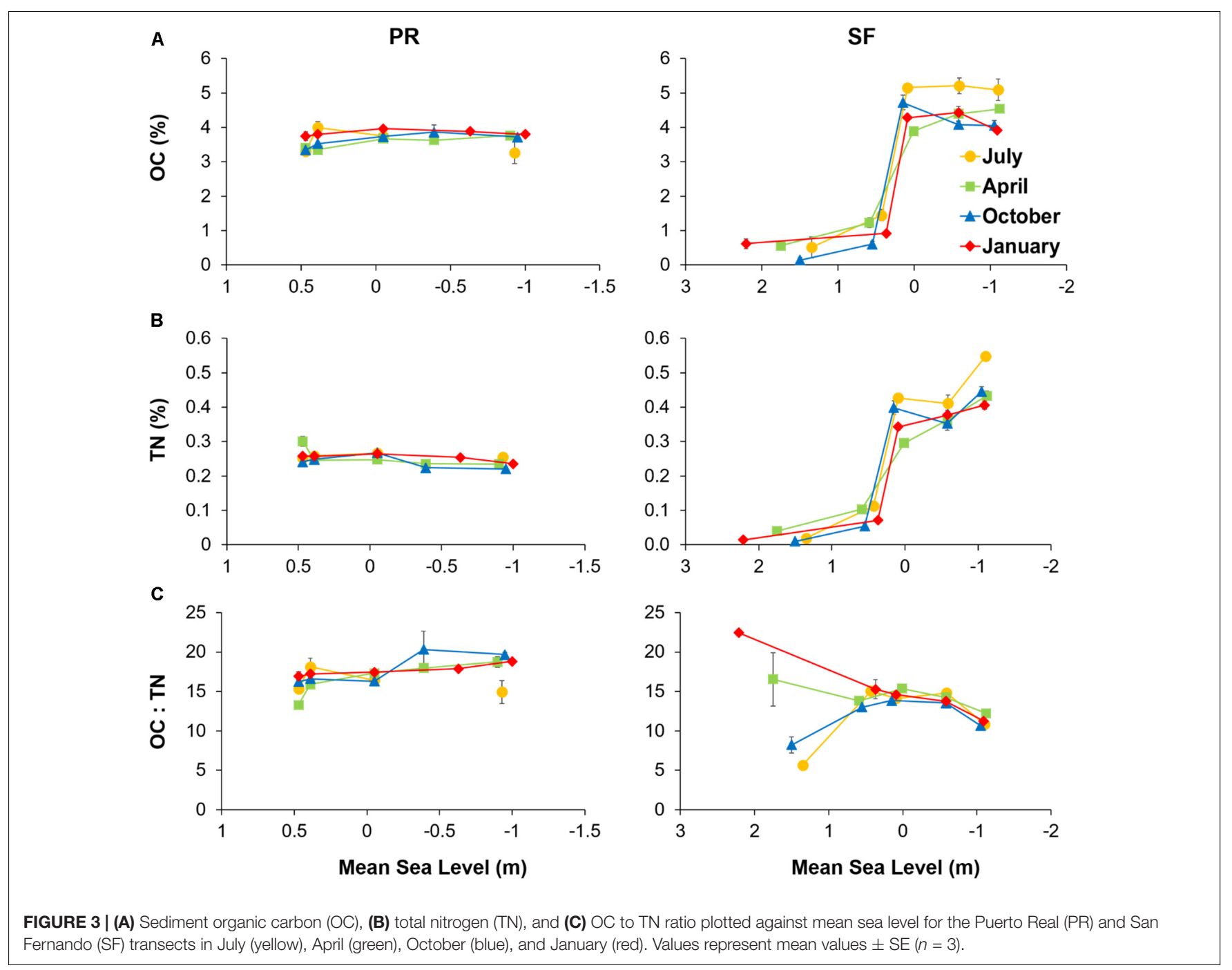

slight decrease in $\mathrm{P}_{\mathrm{N}}$ seawards. No clear pattern was observed over time.

$\mathrm{P}_{\mathrm{N}}$ rates normalized to Chl $a$ content were five times higher in the PR transect $(0.32 \pm 0.1 ; n=5)$ than the SF one $(0.06 \pm 0.1$; $n=5$ ) (Figure 5B). Differences between seasons were more evident in $\mathrm{PR}$ than in SF, with maximum values found in January $(0.44 \pm 0.04 ; n=5)$. In $\mathrm{PR}$, normalized $\mathrm{P}_{\mathrm{N}}$ tended to increase seawards, whereas the opposite was true in winter. In SF, normalized $\mathrm{P}_{\mathrm{N}}$ decreased slightly seaward, with $\mathrm{P}_{\mathrm{N}}$ turning negative at station SF5.

Temporal patterns of $\mathrm{R}_{\mathrm{D}}$ did not coincide between the two transects (Figure 5C). Although $\mathrm{R}_{\mathrm{D}}$ was maximum in January and April in both $\mathrm{PR}$ and $\mathrm{SF}, \mathrm{R}_{\mathrm{D}}$ rates varied between seasons more in PR than in SF. Overall, a trend of decreasing rates was observed seawards in PR.

\section{Interaction Between Environmental Variables}

Principal components with eigenvalues higher than 1 explained 81.48 and $82.10 \%$ of the total variation of the PR and SF transects, respectively (Table 1). PC1 and PC2 explained approximately half of that variation (41.94 and 53.39\% of the variance in PR and SF transects, respectively) (Figure 6). In PR, PC1 was mainly related with irradiance, temperature, salinity and water column nutrient concentrations, and PC2 with shore distance, MSL, and grain size. In SF, PC1 correlated with distance, MSL, grain size, and porewater nutrients, and PC2 with temperature, salinity, irradiance, and water column DSi concentration. OC presented high correlation with PC1 in both transects, slightly higher in SF. Around 12 and 13\% of the variance in environmental variables (PC3) was attributed to rainfall in both transects. Overall, according to our PCA analysis, spatial variability dominated in SF in contrast to PR where temporal variability dominated (Figure 6).

\section{Factors Controlling MPB Biomass}

The PC axes selected by MRL analyses to explain the variations in time and space of the MPB biomass (estimated here by the Chl $a$ content) in each transect accounted for $30 \%$ of the total variation. In PR, MPB biomass was best explained by PC2 


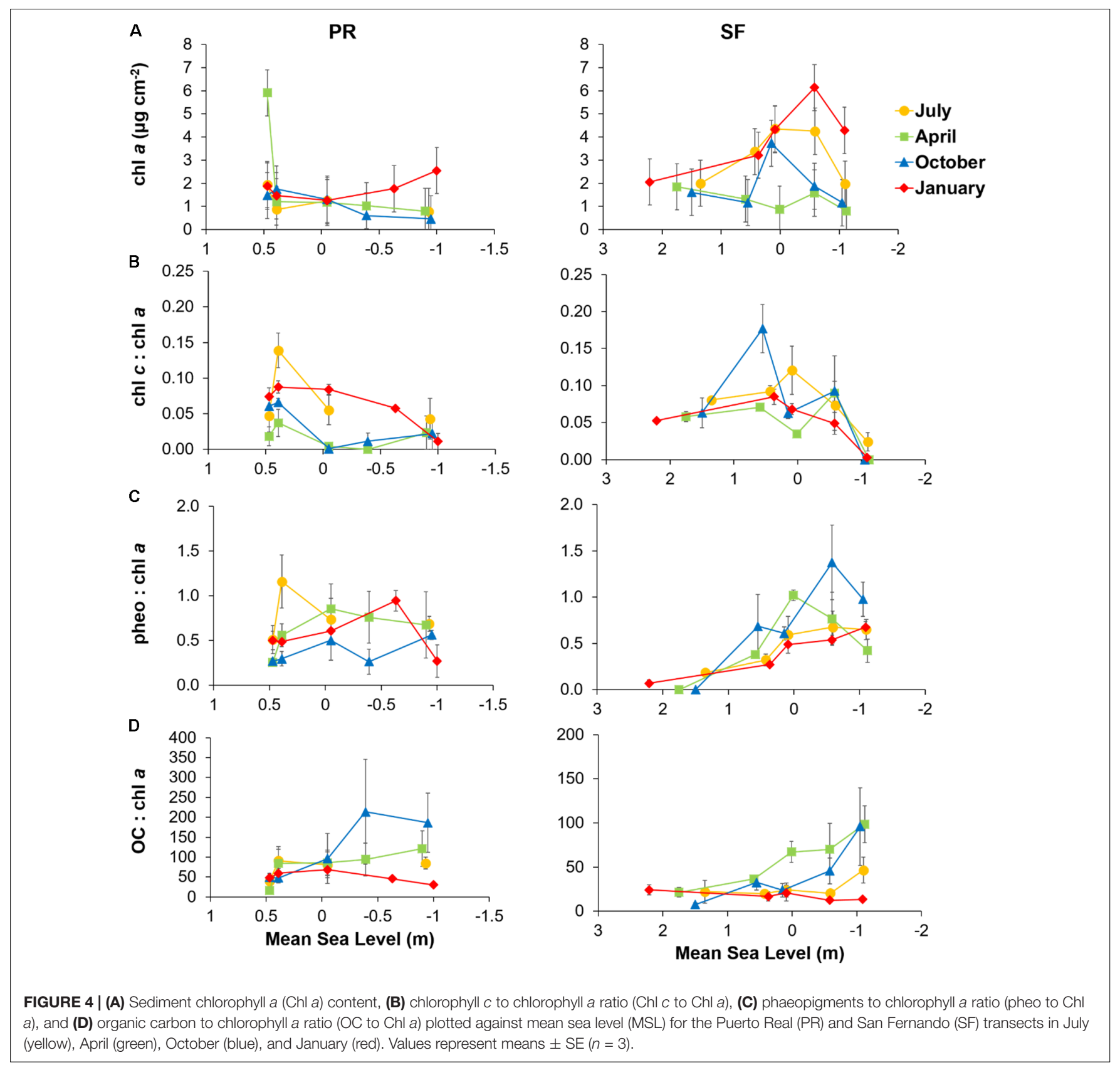

(Table 2) composed primarily by shore distance, MSL, grain size, and TN (Table 1). On the other hand, MPB biomass in SF was explained mainly by PC5 (Table 2), related to $\mathrm{NH}_{4}{ }^{+}$in the water column (Table 1), and to a lesser extent by PC2 which was related to temperature, salinity, irradiance, and DSi concentration in the water column.

\section{Factors Controlling MPB Biomass and Sediment Metabolism}

Principal component scores and MPB biomass (Chl $a$ and $\mathrm{Chl} c$ ) were used as independent variables in MLR to explain $\mathrm{P}_{\mathrm{N}}$ in Cadiz Bay. In PR, $60 \%$ of the variance in $\mathrm{P}_{\mathrm{N}}$ was explained by $\mathrm{Chl}$ $a$ and PC1 (Table 2). Irradiance, temperature, salinity, and wind speed were positively correlated with $\mathrm{PC} 1$, while $\mathrm{OC}, \mathrm{PO}_{4}{ }^{3-}$, and $\mathrm{NH}_{4}{ }^{+}$in water column showed negative correlation with PC1 (Table 1). In SF, the variables tested could only explain $25 \%$ of the variation in $\mathrm{P}_{\mathrm{N}}$. The variables that significantly contributed to explaining this variability were Chl $c$ and PC1 (Table 2). In SF, PC1 was negatively associated with MSL and positively with grain size, porosity, TN, OC, shore distance, and porewater nutrients (except $\mathrm{PO}_{4}{ }^{3-}$ ) (Table 1).

Environmental variables explained 41 and $25 \%$ of $\mathrm{R}_{\mathrm{D}}$ in $\mathrm{PR}$ and SF, respectively (Table 2 ). In PR, PC3 and PC4 contributed significantly to explain variation in $\mathrm{R}_{\mathrm{D}}$. PC3 correlated with rainfall, DSi in the water column and $\mathrm{NO}_{3}{ }^{-}$and $\mathrm{NH}_{4}{ }^{+}$in the 

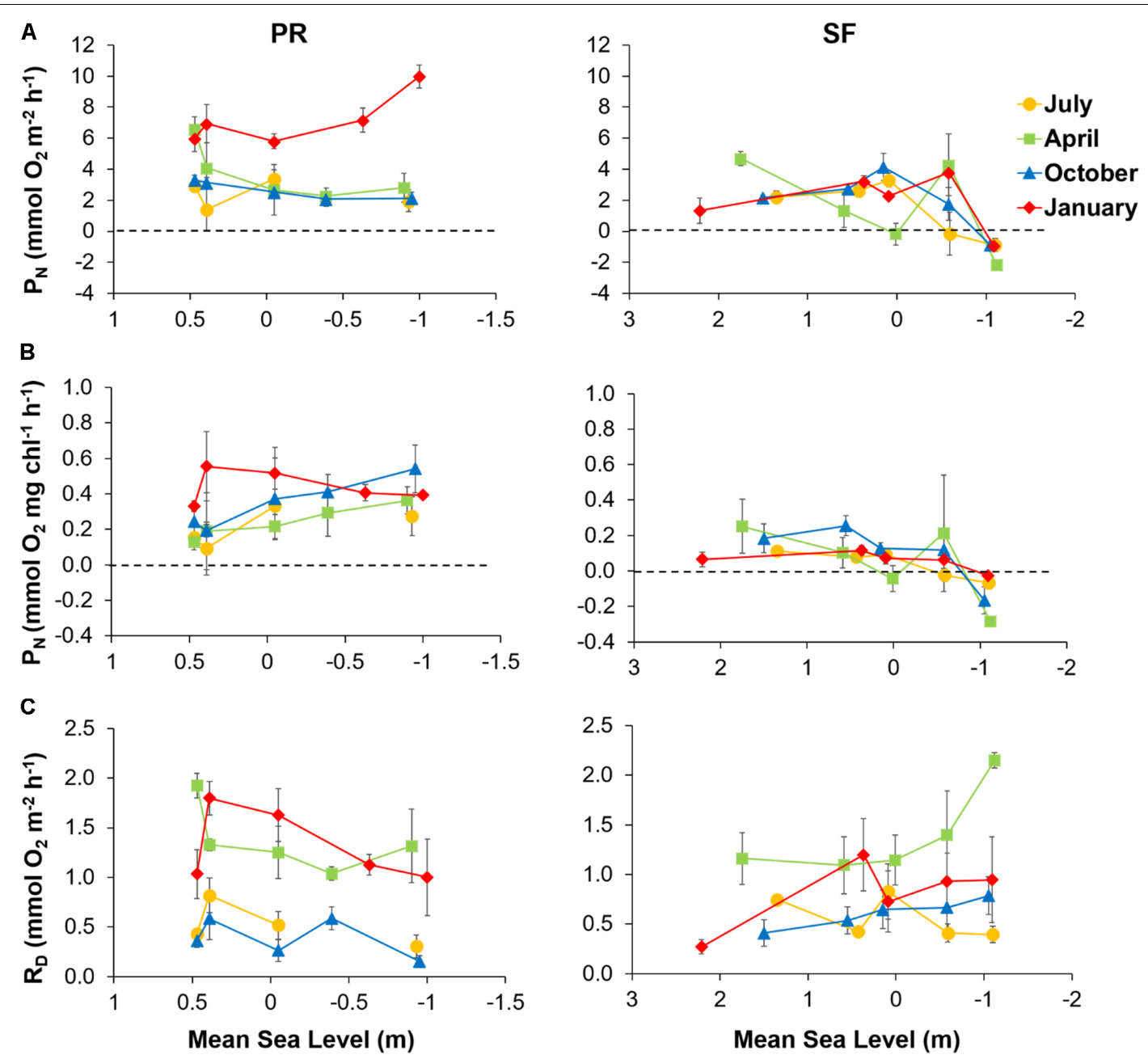

FIGURE 5 | (A) Net production in the photic layer $\left(P_{N}\right)$, (B) respiration in darkness $\left(R_{D}\right)$, and $(\mathbf{C}) P_{N}$ normalized by MPB biomass plotted against mean sea level (MSL) along the Puerto Real (PR) and San Fernando (SF) transects in July (yellow), April (green), October (blue), and January (red). Values represent means \pm SE $(n=3)$.

porewater. PC4 was composed mostly by $\mathrm{NO}_{3}{ }^{-}$in the water column (Table 1). PC3 was the most influential variable of the two (Table 2). In SF, the variables selected were PC3 and PC1 (Table 2). In this case, PC3 was positively correlated with rainfall and negatively with wind speed (Table 1). PC1, as mentioned previously, was associated with MSL and grain size related variables (Table $\mathbf{1}$ ).

\section{Annual Net Metabolism of the Microbenthic Intertidal Sediment}

Daily microphytobenthic rates of $\mathrm{P}_{\mathrm{N}}$ and $\mathrm{R}_{\mathrm{D}}$ were integrated for every season for all seabed types. Microbenthic net metabolism was positive in all seasons except in April in $Z$. noltei sediments (Figure 7$)$. The annual net metabolism of $\mathrm{MPB}\left(\mathrm{P}_{\mathrm{N}}-\mathrm{R}_{\mathrm{D}}\right)$ in bare muddy sediment (PR transect), in bare sandy sediment (SF12 ), and seagrass meadow sediment (SF3-4) was 73.3, 29.6, and $19.5 \mathrm{~g} \mathrm{C} \mathrm{m}^{-2}$, respectively. Given that there was no indication of MPB being present in C. prolifera sediment, this habitat was not considered (SF5).

\section{DISCUSSION}

\section{Biogeochemical Properties of Intertidal Sediments in Cadiz Bay}

The inner Cadiz bay is a complex system, comprising of salt marshes, intertidal flats, seagrass meadows, and shallow subtidal areas. The two transects studied here showed clear differences in their elevation profiles, sediment granulometry, and vegetation cover, as a result of the hydrodynamic conditions and sediment morphodynamics in the bay (Kagan et al., 2003). The PR transect was more homogenous, dominated by fine sediment, without permanent vegetation, and a gentler slope across the gradient (Figure 1). Fine grain sediment, as that found in the PR transect, is the predominant sediment type within the bay (Sanchez De Lamadrid Rey and Muñoz Pérez, 1994; Carrasco et al., 2003). In contrast, the SF transect was more variable in terms of grain size distribution, showing also a steeper slope. In addition, the sediment in the SF transect was colonized by $Z$. noltei and C. prolifera, typical species of the vegetational zonation of 
TABLE 1 | Correlation coefficients between environmental variables and significant components obtained by principal components analysis (wherein the selected components account for over $80 \%$ of environmental variability) for each of the two transects studied in Puerto Real (PR) and San Fernando (SF) seasonally during on year.

\begin{tabular}{|c|c|c|c|c|c|c|c|c|c|c|c|c|}
\hline & \multicolumn{7}{|c|}{ PR } & \multicolumn{5}{|c|}{ SF } \\
\hline & PC1 & PC2 & PC3 & PC4 & PC5 & PC6 & PC7 & PC1 & PC2 & PC3 & PC4 & PC5 \\
\hline Dist. & -0.341 & 0.801 & 0.089 & -0.177 & -0.224 & 0.152 & 0.320 & 0.812 & -0.094 & 0.103 & -0.089 & -0.137 \\
\hline MSL & 0.306 & -0.758 & -0.070 & 0.149 & 0.321 & -0.254 & -0.298 & -0.921 & 0.025 & -0.130 & 0.048 & 0.096 \\
\hline Grain size $<63 \mu \mathrm{m}$ & 0.021 & -0.740 & 0.233 & -0.228 & -0.102 & 0.419 & -0.211 & 0.940 & -0.006 & 0.150 & -0.074 & 0.026 \\
\hline$\Phi$ & -0.227 & 0.584 & 0.374 & -0.322 & 0.204 & 0.021 & 0.025 & 0.919 & 0.032 & 0.153 & -0.103 & -0.038 \\
\hline Rain & -0.125 & 0.006 & 0.786 & 0.089 & -0.163 & -0.271 & -0.258 & -0.178 & 0.166 & 0.756 & 0.182 & -0.433 \\
\hline Rad. & 0.813 & 0.383 & -0.177 & -0.156 & 0.309 & -0.041 & -0.049 & 0.228 & 0.749 & -0.594 & -0.070 & 0.116 \\
\hline Temp. & 0.788 & 0.376 & 0.150 & -0.208 & 0.291 & -0.097 & -0.156 & 0.178 & 0.903 & -0.163 & -0.170 & 0.091 \\
\hline Wind & 0.485 & 0.353 & -0.477 & 0.448 & -0.034 & -0.298 & 0.074 & 0.157 & 0.563 & -0.697 & 0.257 & -0.199 \\
\hline Sal. & 0.723 & -0.044 & 0.269 & -0.042 & -0.157 & 0.004 & -0.025 & -0.184 & 0.655 & 0.497 & -0.172 & -0.102 \\
\hline WC.DSi & 0.520 & 0.072 & 0.588 & -0.004 & 0.384 & -0.100 & 0.261 & -0.202 & 0.876 & 0.164 & -0.105 & 0.237 \\
\hline WC.PO4 & -0.627 & -0.358 & 0.386 & 0.202 & 0.201 & -0.070 & 0.252 & -0.394 & 0.424 & 0.412 & 0.499 & 0.051 \\
\hline WC.NO3 & -0.205 & 0.459 & -0.064 & 0.543 & 0.169 & 0.038 & -0.431 & 0.055 & -0.009 & -0.167 & 0.791 & -0.004 \\
\hline WC.NH4 & -0.659 & 0.001 & 0.168 & 0.530 & 0.166 & -0.116 & 0.107 & 0.133 & -0.374 & 0.036 & 0.214 & 0.836 \\
\hline PW.DSi & 0.499 & -0.220 & 0.091 & 0.376 & -0.223 & -0.110 & 0.522 & 0.585 & 0.061 & -0.076 & 0.556 & -0.215 \\
\hline PW.PO4 & 0.401 & 0.151 & -0.244 & 0.415 & -0.085 & 0.628 & -0.063 & 0.318 & 0.473 & 0.440 & 0.236 & 0.323 \\
\hline PW.NO3 & -0.368 & -0.020 & -0.504 & -0.180 & 0.488 & -0.065 & 0.154 & 0.675 & -0.065 & -0.441 & 0.153 & -0.142 \\
\hline PW.NH4 & 0.322 & 0.183 & 0.567 & 0.340 & 0.302 & 0.406 & 0.042 & 0.633 & -0.036 & 0.243 & 0.397 & 0.082 \\
\hline OC & -0.638 & 0.109 & -0.105 & -0.030 & 0.457 & 0.207 & -0.020 & 0.923 & 0.044 & 0.111 & -0.205 & 0.079 \\
\hline TN & 0.350 & -0.595 & -0.160 & -0.054 & 0.266 & 0.184 & 0.354 & 0.941 & 0.042 & 0.172 & -0.186 & 0.056 \\
\hline
\end{tabular}

Nutrients in the porewater were $\log (x+1)$ transformed. Values in bold correspond to the axis for which the squared cosine of the specific variable is the largest. Dist.,

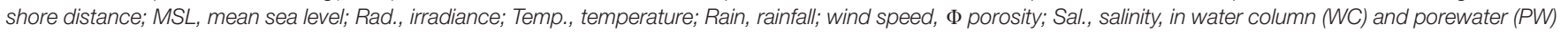
nutrients $\left(\mathrm{DSi}, \mathrm{NO}_{2}{ }^{-}+\mathrm{NO}_{3}^{-}, \mathrm{PO}_{4}{ }^{3-}\right.$ and $\left.\mathrm{NH}_{4}{ }^{+}\right)$, OC organic carbon, and TN total nitrogen.

the inner Cadiz Bay benthic environment (Figure 1) (Gómez Ordoñez, 2008). These macrophytes can significantly contribute to the accumulation of finer grained sediment (Peralta et al., 2008; Greiner et al., 2016), which might explain the differences along the SF transect with increased fines content in the middle and lower intertidal.

Water column nutrients showed little differences between transects probably due to the relatively small distance between sampling points within the transect and the increased mixing in the water column due to tides and wind action (Kagan et al., 2003). Nonetheless, water column DSi and $\mathrm{PO}_{4}{ }^{3-}$ tended to decrease seaward along the transects, indicating that the upper intertidal near the saltmarsh might act as a potential source of DSi and $\mathrm{PO}_{4}{ }^{3-}$, whereas concentrations of $\mathrm{NO}_{3}{ }^{-}$and $\mathrm{NH}_{4}{ }^{+}$were rather constant. Interestingly, nutrient concentrations in the porewater followed an inverse trend to that observed in the water column, i.e., they tended to increase seaward. Nutrient concentrations in both the water column and the porewater were similar to those measured previously in the bay (Garcia-Robledo et al., 2016), with the exception of DSi. Concentrations of DSi in the porewater, particularly in SF, were up to $50 \mathrm{nmol} \mathrm{cm} \mathrm{cm}^{-3}$, double the maximum measured previously (Garcia-Robledo et al., 2016). Overall, higher nutrients concentrations in the porewater were measured in SF with a trend of increasing values seaward, in the presence of the seagrass $Z$. noltei at SF3 and SF4. This is not surprising since seagrass sediments are able to temporarily retain a high amount of nitrogen due to the trapping of particles from the water column, the biological immobilization of decomposing plant tissues via burial, and the stimulation of nitrogen fixation (Risgaard-Petersen et al., 1998; Barrón et al., 2006).

Stoichiometric ratios of inorganic nutrients (i.e., DSi:N and $\mathrm{N}: \mathrm{P}$ ) in the water column seem to indicate that MPB in Cadiz Bay could be strongly limited by $\mathrm{P}$ since the N:P ratio was generally higher than 22 (Hillebrand and Sommer, 1999). On the other hand, the DSi to $\mathrm{N}$ ratio was lower than 0.8 suggesting limitation by DSi, mainly in winter in both transects (Justiæ et al., 1995). In our study, we did not find any positive correlation between $\mathrm{P}_{\mathrm{N}}$ or biomass and water column DSi, like the ones observed previously for MPB (Welker et al., 2002; Garcia-Robledo et al., 2016). In addition, a recent experimental study using sediment from the inner Bay of Cadiz has demonstrated that water column DSi concentration affects MPB primary production but not its biomass (Bohórquez et al., 2019). Although these data might suggest a DSi and P limitation which might affect the growth of diatoms (Cibic et al., 2007), previous published observations for sediments of the wider area (Garcia-Robledo et al., 2008, 2012; Haro et al., 2019) and preliminary data based on molecular analyses for intertidal sediments of the inner bay (J. Taylor pers comm) suggest that diatoms are ubiquitous and are the dominant microalgal group. Nevertheless, further analyses are required to quantify the contribution of the various algal groups to the MPB community composition along the intertidal area of Cádiz Bay and study the drivers behind possible community shifts in space and time. 


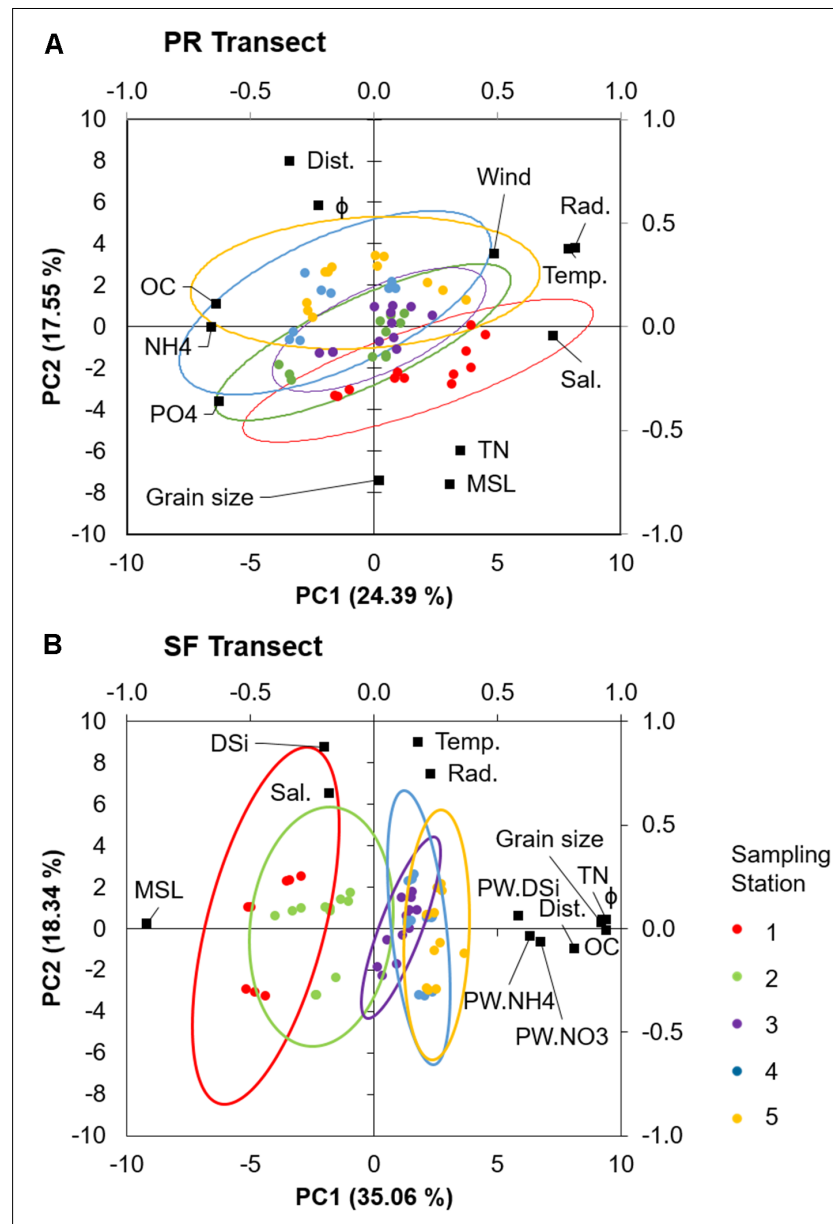

FIGURE 6 | Principal components analysis of environmental variables for the (A) Puerto Real (PR) and (B) San Fernando (SF) transects. Only variables for which the squared cosine is the largest in each axis are shown. Colored symbols represent the five stations sampled at each transect during the four sampling campaigns. The ellipses represent 95\% confidence intervals for each station.

Sediment OC content variations were mainly related to sediment grain size, with limited variations over time. Thus, in PR, where the sediment was homogeneous and lacked areas with permanent macrophytes, no variations in OC were observed (Figure 3A) and values were similar to those measured previously in the inner bay (Papaspyrou et al., 2013; Jimenez-Arias et al., 2016). In SF, however, organic matter content changed drastically with grain size. OC values were $\sim 4$ times higher in stations SF3-SF5, indicating a high input of OC to sediment, presumably from macrophyte detritus and exudates, as well as fine particles trapped within the meadows (Peralta et al., 2008; Greiner et al., 2016). This highlights the importance of macrophytes for the accumulation and burial of organic matter in vegetated areas, especially in the shallow inner Cadiz Bay (Jimenez-Arias et al., 2016).

Sediment $\mathrm{OC}$ to $\mathrm{TN}$ ratio, albeit slightly higher in $\mathrm{PR}$, was similar in both transects, except in SF1 (Figure 3C). C:N ratios greater than 7.5 indicate sources of organic matter, other than microphytobenthic production (Hillebrand and Sommer, 1999) or high N mineralization rates (Sundbäck et al., 2004). The OC to $\mathrm{TN}$ ratios observed here were slightly higher than those found previously in muddy sediments close to the PR transect ( 10, Jimenez-Arias et al., 2016) and other intertidal flats (De Jonge, 1980; Oakes et al., 2010; Lee et al., 2018). On the other hand, a slight decrease in the OC to TN ratio at SF5 could be due to increased nitrogen fixation observed in C. prolifera beds (Chisholm and Moulin, 2003). At SF5, an increase in the OC to Chl $a$ ratio (Figure 4D) was also observed suggesting an increase in fresh non-photosynthetic labile OC associated with particulate matter accumulated due to hydrodynamic effects within the canopy (Hendriks et al., 2010; Lara et al., 2016) or organic matter exudates by C. prolifera (Ruiz-Halpern et al., 2014).

\section{Temporal and Spatial Patterns in the MPB Biomass}

Microphytobenthos biomass patterns depend on the tight interaction between abiotic factors, such as light, nutrient availability, and resuspension, and biotic ones, such as grazing. Most studies on MPB have been conducted in intertidal areas of northern European estuaries and coastal settings with a humid continental climate (latitudes $>45^{\circ}$ ) (Table 3 ). In these regions, an annual maximum of biomass is found usually in summer, when higher temperatures and increased irradiance occur (Migné et al., 2004; Davoult et al., 2009; Van der Wal et al., 2010; Orvain et al., 2012), although in some cases different patterns have been found (Colijn and De Jonge, 1984; Underwood and Paterson, 1993; Thornton et al., 2002). In contrast, in southern European estuaries, with Mediterranean climate, the opposite temporal pattern is usually observed. In the Tagus estuary, for example, the MPB biomass was studied seasonally by remote sensing and was found to be maximum in winter (Brito et al., 2013), same as in Cadiz Bay (current study, Garcia-Robledo et al., 2016). Interestingly, studies worldwide in intertidal flats located at a similar latitude (i.e., around $35-38^{\circ}$ ) have found similar patterns with maxima in winter, e.g., the Ariake Sea in Japan (Koh et al., 2007), or the Saemangeum tidal flat in west Korea (Kwon et al., 2016) (Table 3).

Some discrepancies with respect to this general pattern have been reported for French estuaries. The calm conditions and the exposure to sunlight during low tide allow the development of higher MPB biomass in the intertidal zone in the Bay of Somme, the Mont Saint-Michael Bay or the Roscoff Aber Bay, at latitudes between 48 and $50^{\circ}$ (Orvain et al., 2012), in the summer. In contrast, in the Brouage mudflat, at a lower latitude $\left(45^{\circ}\right)$, the highest biomass was reported between winter and early spring due to the grazing and thermo-inhibition in summer (Savelli et al., 2018) (Table 3). In our study, maximum Chl $a$ values were found in winter. In addition to a possible thermo-inhibition, the lower MPB biomass in the summer could be a consequence of the combined effects of resuspension, turbidity, and grazing pressure. In Cadiz Bay, extreme wind events are especially frequent during summer and are known to increase sediment resuspension and turbidity, as well as produce sediment surface desiccation (Supplementary Figure 1) (Gutiérrez et al., 2000; 
TABLE 2 | Multiple linear regression analysis of chlorophyll a, $P_{N}$ in light, and $R_{D}$ in darkness against the component variables obtained from the PCA analyses of the environmental variables for the Puerto Real (PR) and San Fernando (SF) transects.

\begin{tabular}{|c|c|c|c|c|c|c|c|c|c|c|}
\hline \multirow[b]{2}{*}{ Variables } & \multicolumn{5}{|c|}{ PR } & \multicolumn{5}{|c|}{ SF } \\
\hline & Value & Standard error & $t$ & $\operatorname{Pr}>|t|$ & Adjusted $R^{2}$ & Value & Standard error & $t$ & $\operatorname{Pr}>|t|$ & Adjusted $R^{2}$ \\
\hline \multicolumn{11}{|l|}{ Biomass } \\
\hline Intercept & 0.850 & 0.043 & 19.729 & $<0.0001$ & 0.330 & 1.163 & 0.053 & 22.135 & $<0.0001$ & 0.363 \\
\hline PC2 & -0.121 & 0.024 & -5.119 & $<0.0001$ & & -0.079 & 0.028 & -2.810 & 0.007 & \\
\hline PC5 & & & & & & 0.241 & 0.047 & 5.103 & $<0.0001$ & \\
\hline PC6 & 0.075 & 0.041 & 1.832 & 0.073 & & & & & & \\
\hline \multicolumn{11}{|l|}{$P_{N}$ in light } \\
\hline Intercept & 0.044 & 0.535 & 0.081 & 0.935 & 0.608 & 0.568 & 0.492 & 1.154 & 0.254 & 0.251 \\
\hline Chl a & 4.729 & 0.573 & 8.256 & $<0.0001$ & & & & & & \\
\hline Chl c & & & & & & 9.167 & 2.736 & 3.350 & 0.001 & \\
\hline PC1 & -0.635 & 0.105 & -6.059 & $<0.0001$ & & -0.329 & 0.121 & -2.716 & 0.009 & \\
\hline \multicolumn{11}{|c|}{$\mathbf{R}_{\mathbf{D}}$ in darkness } \\
\hline Intercept & 0.919 & 0.060 & 15.339 & $<0.0001$ & 0.414 & 0.848 & 0.066 & 12.948 & $<0.0001$ & 0.247 \\
\hline PC1 & & & & & & 0.065 & 0.025 & 2.553 & 0.014 & \\
\hline PC3 & -0.210 & 0.039 & -5.417 & $<0.0001$ & & -0.155 & 0.042 & -3.724 & 0.000 & \\
\hline PC4 & 0.168 & 0.048 & 3.505 & 0.001 & & & & & & \\
\hline
\end{tabular}

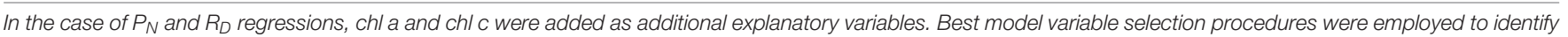

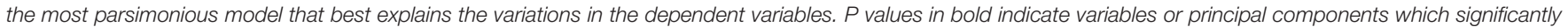
contributed to explain the patterns in MPB biomass, PN or RD according to the multiple linear regression analysis.

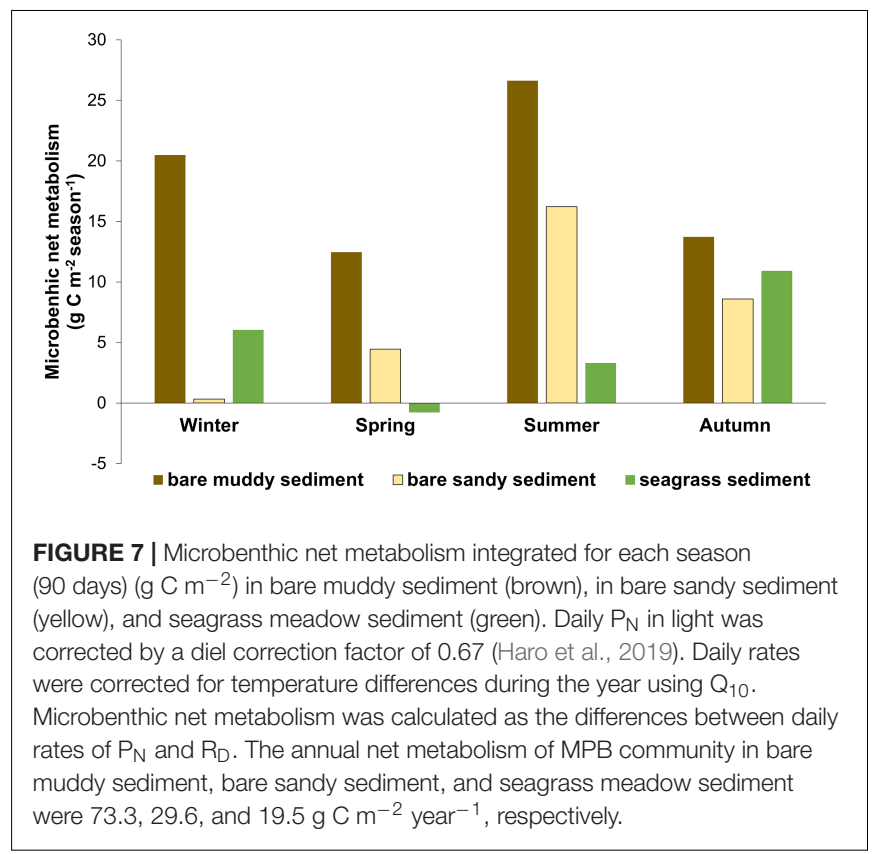

Kagan et al., 2003; Lara et al., 2018). In terms of grazing, higher rates have been reported for summer elsewhere, particularly during emersion (Cariou-Le Gall and Blanchard, 1995; Coelho et al., 2011). Available studies on the abundance of potential grazers in the inner Cadiz Bay (i.e., meiofauna) show variable results; higher meiofaunal abundance in the months of January and July in one case (Papaspyrou et al. unpubl. data) or in May in another (Bohórquez et al., 2013), therefore, the effect of grazing on the patterns observed in our transects cannot be evaluated at present.

Spatial patterns of MPB biomass studied here differed seasonally and between locations. At the muddy transect (PR), an increase seaward was observed during winter (i.e., the most productive period) whereas during the warmest months of the year values were more homogeneous or showed a slightly inverse trend. The seaward increase in winter seems to contrast with the spatial variations reported in other estuaries and tidal flats (Jesus et al., 2009; Van der Wal et al., 2010; Orvain et al., 2012; Brito et al., 2013; Kwon et al., 2016). These studies attributed the higher MPB biomass upper shore to the longer light exposure there and the decreased biomass lower shore to the light attenuation by the water column limiting MPB growth. However, although irradiance dosage is higher in the upper shore, the additional amount of light cannot be fully absorbed by the sediment due to a higher reflectance in emersion. This has been experimentally demonstrated for irradiances of up to $800 \mu \mathrm{mol}$ photon $\mathrm{m}^{-2} \mathrm{~s}^{-1}$ in sandy (Kühl and Jorgensen, 1994; Haro et al., 2019), as well as muddy sediments (Balsam et al., 1998). Regardless, in Cadiz Bay and other intertidal systems located at lower latitudes, light limitation is generally lower in the lower shore because the incident solar irradiance is higher. Moreover, the lower intertidal experiences a shorter desiccation period which together with the higher solar irradiance could explain the higher biomass values found here. Nevertheless, long term studies integrating larger areas will be needed to determine whether the pattern observed here persists in time.

In the mixed sediment type transect (SF), maximum MPB biomass was found at the intermediate stations SF3 and SF4. The higher MPB biomass at these stations could be due to a positive interaction between MPB and seagrasses present at 
TABLE 3 | Temporal and spatial variability of the MPB biomass (Chl-a), net production in light (PN), gross production (PG), and respiration in darkness (RD) in the intertidal areas of estuaries worldwide at latitudes from 53 to $33^{\circ} \mathrm{N}$.

\begin{tabular}{|c|c|c|c|c|c|c|c|c|c|c|c|c|c|}
\hline \multirow[t]{2}{*}{ Variable } & \multicolumn{4}{|c|}{ Estuary characteristics } & \multicolumn{2}{|c|}{ Seasonal variability } & \multicolumn{2}{|c|}{ Spatial variability } & \multicolumn{2}{|c|}{ Temporal resolution } & \multirow{2}{*}{$\begin{array}{l}\begin{array}{l}\text { Spatial } \\
\text { resolution }\end{array} \\
\text { Grid or } \\
\text { Transect } \\
\text { length (m) } \\
\text { (Numbers } \\
\text { of sampling } \\
\text { stations) }\end{array}$} & \multirow{2}{*}{$\begin{array}{l}\text { Analysis } \\
\text { method }\end{array}$} & \multirow[t]{2}{*}{ References } \\
\hline & Estuary & Country & Latitude & Substrate & Maximum & Minimum & Maximum & Minimum & & & & & \\
\hline \multicolumn{14}{|l|}{ Biomass } \\
\hline NDVI & Wadden Sea & Netherlands & $53^{\circ} 20^{\prime} \mathrm{N}$ & Sandy & June & December & Upper & Lower & Monthly & $\begin{array}{l}2002- \\
2008\end{array}$ & $250 \times 250$ & RS & $\begin{array}{l}\text { Van der Wal } \\
\text { et al., } 2010\end{array}$ \\
\hline NDVI & Ems-Dollard & Netherlands & $53^{\circ} 25^{\prime} \mathrm{N}$ & $\begin{array}{l}\text { Muddy- } \\
\text { sandy }\end{array}$ & June & December & Upper & Lower & Monthly & $\begin{array}{l}2002- \\
2008\end{array}$ & 250250 & RS & $\begin{array}{l}\text { Van der Wal } \\
\text { et al., } 2010\end{array}$ \\
\hline NDVI & Westerschelde & Netherlands & $51^{\circ} 20^{\prime} \mathrm{N}$ & Sandy & May & December & Patch & Patch & Monthly & $\begin{array}{l}2002- \\
2008\end{array}$ & $250 \times 250$ & RS & $\begin{array}{l}\text { Van der Wal } \\
\text { et al., } 2010\end{array}$ \\
\hline NDVI & Oosterschelde & Netherlands & $51^{\circ} 35^{\prime} \mathrm{N}$ & Sandy & October & December & Patch & Patch & Monthly & $\begin{array}{l}2002- \\
2008\end{array}$ & $250 \times 250$ & RS & $\begin{array}{l}\text { Van der Wal } \\
\text { et al., } 2010\end{array}$ \\
\hline NDVI & Thames & $\begin{array}{l}\text { United } \\
\text { Kingdom }\end{array}$ & $51^{\circ} 35^{\prime} \mathrm{N}$ & $\begin{array}{l}\text { Muddy- } \\
\text { sandy }\end{array}$ & $\begin{array}{l}\text { March- } \\
\text { July }\end{array}$ & December & Upper & Lower & Monthly & $\begin{array}{l}2002- \\
2008\end{array}$ & $250 \times 250$ & RS & $\begin{array}{l}\text { Van der Wal } \\
\text { et al., } 2010\end{array}$ \\
\hline NDVI & Wash & $\begin{array}{l}\text { United } \\
\text { Kingdom }\end{array}$ & $52^{\circ} 55^{\prime} \mathrm{N}$ & $\begin{array}{l}\text { Muddy- } \\
\text { sandy }\end{array}$ & August & December & Upper & Lower & Monthly & $\begin{array}{l}2002- \\
2008\end{array}$ & $250 \times 250$ & RS & $\begin{array}{l}\text { Van der Wal } \\
\text { et al., } 2010\end{array}$ \\
\hline NDVI & Humber & $\begin{array}{l}\text { United } \\
\text { Kingdom }\end{array}$ & $53^{\circ} 35^{\prime} \mathrm{N}$ & $\begin{array}{l}\text { Muddy- } \\
\text { sandy }\end{array}$ & September & December & Upper & Lower & Monthly & $\begin{array}{l}2002- \\
2008\end{array}$ & $250 \times 250$ & $\mathrm{RS}$ & $\begin{array}{l}\text { Van der Wal } \\
\text { et al., } 2010\end{array}$ \\
\hline NDVI & Brillantes_Loire & France & $47^{\circ} 17^{\prime} \mathrm{N}$ & $\begin{array}{l}\text { Muddy- } \\
\text { sandy }\end{array}$ & - & - & & - & Interannual & $\begin{array}{l}1991- \\
2009\end{array}$ & $20 \times 20$ & RS & $\begin{array}{l}\text { Benyoucef } \\
\text { et al., } 2013\end{array}$ \\
\hline NDVI & Lavau_Loire & France & $47^{\circ} 17^{\prime} \mathrm{N}$ & Mud & - & - & & - & Interannual & $\begin{array}{l}1991- \\
2009\end{array}$ & $20 \times 20$ & $\mathrm{RS}$ & $\begin{array}{l}\text { Benyoucef } \\
\text { et al., } 2013\end{array}$ \\
\hline NDVI & $\begin{array}{l}\text { Brouage } \\
\text { mudflat }\end{array}$ & France & $45^{\circ} 54^{\prime} \mathrm{N}$ & Mud & March & $\begin{array}{l}\text { May- } \\
\text { August }\end{array}$ & - & - & $\begin{array}{l}\text { February \& } \\
\text { July; April, } \\
\text { July \& } \\
\text { November; } \\
\text { February \& } \\
\text { April }\end{array}$ & $\begin{array}{l}2008 \\
2012 \\
2013\end{array}$ & $250 \times 250$ & RS & $\begin{array}{l}\text { Savelli et al., } \\
2018\end{array}$ \\
\hline NDVI & $\begin{array}{l}\text { Tagus, A } \\
\text { Transect }\end{array}$ & Portugal & $38^{\circ} 44^{\prime} \mathrm{N}$ & $\begin{array}{l}\text { Muddy- } \\
\text { sandy }\end{array}$ & & - & Upper & $\begin{array}{l}\text { Middle- } \\
\text { lower }\end{array}$ & Bimonthly & $\begin{array}{l}2002- \\
2004\end{array}$ & $270(3)$ & NDVI & $\begin{array}{l}\text { Jesus et al., } \\
2009\end{array}$ \\
\hline NDVI & $\begin{array}{l}\text { Tagus. V } \\
\text { Transect }\end{array}$ & Portugal & $38^{\circ} 44^{\prime} \mathrm{N}$ & $\begin{array}{l}\text { Muddy- } \\
\text { sandy }\end{array}$ & - & - & $\begin{array}{l}\text { Middle- } \\
\text { lower }\end{array}$ & Upper & Bimonthly & $\begin{array}{l}2002- \\
2004\end{array}$ & $270(3)$ & NDVI & $\begin{array}{l}\text { Jesus et al., } \\
2009\end{array}$ \\
\hline NDVI & Tagus & Portugal & $38^{\circ} 44^{\prime} \mathrm{N}$ & Mud & December & May & Upper & Lower & $\begin{array}{l}\text { December- } \\
\text { April }\end{array}$ & $\begin{array}{l}2002- \\
2003\end{array}$ & $20 \times 20$ & RS & $\begin{array}{l}\text { Brito et al., } \\
2013\end{array}$ \\
\hline Chl-a & Colne & $\begin{array}{l}\text { United } \\
\text { Kingdom }\end{array}$ & $51^{\circ} 50^{\prime} \mathrm{N}$ & Mud & Fall & Spring & $\begin{array}{l}\text { Upper- } \\
\text { middle }\end{array}$ & Lower & Monthly & $\begin{array}{l}1996- \\
1998\end{array}$ & $10000(4)$ & $\begin{array}{l}\text { SC; } \\
\text { Spec }\end{array}$ & $\begin{array}{l}\text { Thornton } \\
\text { et al., } 2002\end{array}$ \\
\hline Chl-a & $\begin{array}{l}\text { Bay of Somme, } \\
\text { English } \\
\text { Channel }\end{array}$ & France & $50^{\circ} 13^{\prime} \mathrm{N}$ & Sandy & June & January & - & - & Quarterly & 2000-2001 & $-(1)$ & $\begin{array}{l}\text { SC; } \\
\text { Spec }\end{array}$ & $\begin{array}{l}\text { Migné et al., } \\
2004\end{array}$ \\
\hline
\end{tabular}


TABLE 3 | Continued

Estuary characteristics

Seasonal variability

Spatial variability

T

Temporal resolution

Analysis References resolution method

\begin{tabular}{|c|c|c|c|c|c|c|}
\hline Estuary & Country & Latitude & Substrate & Maximum & Minimum & Maximum \\
\hline
\end{tabular}

resolution

\section{Grid or}

Transect

length $(\mathrm{m})$

(Numbers

stations)

\begin{tabular}{|c|c|c|c|c|c|c|c|c|c|c|c|c|c|}
\hline Chl-a & $\begin{array}{l}\text { Baie des Veys, } \\
\text { English } \\
\text { Channel }\end{array}$ & France & $49^{\circ} 22^{\prime} \mathrm{N}$ & $\begin{array}{l}\text { Muddy- } \\
\text { sandy }\end{array}$ & - & - & Upper & Lower & $\begin{array}{l}\text { 14-19 april; } \\
\text { March }\end{array}$ & 2003; 2004 & $\begin{array}{l}500 \times 500 \\
(138)\end{array}$ & $\begin{array}{l}\text { SC; } \\
\text { Spec }\end{array}$ & $\begin{array}{l}\text { Orvain et al., } \\
2012\end{array}$ \\
\hline Chl-a & $\begin{array}{l}\text { Mont } \\
\text { Saint-Michel } \\
\text { Bay. Ca } \\
\text { Transect }\end{array}$ & France & $48^{\circ} 35^{\prime} \mathrm{N}$ & Mud & $\begin{array}{l}\text { Depends } \\
\text { on MSL }\end{array}$ & August & Middle & - & Quarterly & 2003-2004 & 2000 (3) & $\begin{array}{l}\text { SC; } \\
\text { Spec }\end{array}$ & $\begin{array}{l}\text { Davoult et al., } \\
2009\end{array}$ \\
\hline Chl-a & $\begin{array}{l}\text { Mont } \\
\text { Saint-Michel } \\
\text { Bay. Ch } \\
\text { Transect }\end{array}$ & France & $48^{\circ} 35^{\prime} \mathrm{N}$ & Sand & $\begin{array}{l}\text { Depends } \\
\text { on MSL }\end{array}$ & August & Upper & - & Quarterly & 2003-2004 & 2500 (3) & $\begin{array}{l}\text { SC; } \\
\text { Spec }\end{array}$ & $\begin{array}{l}\text { Davoult et al., } \\
2009\end{array}$ \\
\hline Chl-a & $\begin{array}{l}\text { Brouage } \\
\text { mudflat }\end{array}$ & France & $45^{\circ} 54^{\prime} \mathrm{N}$ & Mud & March & September & - & - & $\begin{array}{l}\text { February \& } \\
\text { July; April, } \\
\text { July \& } \\
\text { November; } \\
\text { February \& } \\
\text { April }\end{array}$ & $\begin{array}{l}\text { 2008; } \\
2012 ; 2013\end{array}$ & $250 \times 250$ & $\begin{array}{l}\text { SC; } \\
\text { Spec }\end{array}$ & $\begin{array}{l}\text { Savelli et al., } \\
2018\end{array}$ \\
\hline Chl-a & $\begin{array}{l}\text { Brouage } \\
\text { mudflat in } \\
\text { Marennes- } \\
\text { Oleron } \\
\text { Bay }\end{array}$ & France & $45^{\circ} 50^{\prime} \mathrm{N}$ & Mud & May & December & - & - & $\begin{array}{l}\text { November; } \\
\text { May }\end{array}$ & 2000; 2001 & 2600 (3) & $\begin{array}{l}\text { SC; } \\
\text { Spec }\end{array}$ & $\begin{array}{l}\text { Orvain et al., } \\
2007\end{array}$ \\
\hline Chl-a & $\begin{array}{l}\text { Marennes- } \\
\text { Oleron } \\
\text { Bay }\end{array}$ & France & $45^{\circ} 50^{\prime} \mathrm{N}$ & Mud & June & January & - & - & $\begin{array}{l}\text { June- } \\
\text { January }\end{array}$ & 1995-1996 & $250 \times 250$ & $\begin{array}{l}\text { SC; } \\
\text { Spec }\end{array}$ & $\begin{array}{l}\text { Guarini et al., } \\
1998\end{array}$ \\
\hline Chl-a & Livorno & Italy & $43^{\circ} 47^{\prime} \mathrm{N}$ & Sandstone & September & March & - & - & $\begin{array}{l}\text { March; } \\
\text { September }\end{array}$ & 2012; 2014 & - & $\begin{array}{l}\text { SC; } \\
\text { Spec }\end{array}$ & $\begin{array}{l}\text { Maggi et al., } \\
2017\end{array}$ \\
\hline Chl-a & $\begin{array}{l}\text { Tagus, A } \\
\text { Transect }\end{array}$ & Portugal & $38^{\circ} 44^{\prime} \mathrm{N}$ & $\begin{array}{l}\text { Muddy- } \\
\text { sandy }\end{array}$ & $\begin{array}{l}\text { January- } \\
\text { May }\end{array}$ & November & Upper & $\begin{array}{l}\text { Middle- } \\
\text { lower }\end{array}$ & Bimonthly & 2002-2004 & $270(3)$ & $\begin{array}{l}\text { SC; } \\
\text { Spec }\end{array}$ & $\begin{array}{l}\text { Jesus et al., } \\
2009\end{array}$ \\
\hline Chl-a & $\begin{array}{l}\text { Tagus. V } \\
\text { Transect }\end{array}$ & Portugal & $38^{\circ} 44^{\prime} \mathrm{N}$ & $\begin{array}{l}\text { Muddy- } \\
\text { sandy }\end{array}$ & $\begin{array}{l}\text { January- } \\
\text { May }\end{array}$ & $\begin{array}{l}\text { November } \\
\& \text { July }\end{array}$ & $\begin{array}{l}\text { Middle- } \\
\text { lower }\end{array}$ & Upper & Bimonthly & 2002-2004 & $270(3)$ & $\begin{array}{l}\text { SC; } \\
\text { Spec }\end{array}$ & $\begin{array}{l}\text { Jesus et al., } \\
2009\end{array}$ \\
\hline Chl-a & Tagus & Portugal & $38^{\circ} 44^{\prime} \mathrm{N}$ & Mud & January & - & Upper & Lower & $\begin{array}{l}\text { December- } \\
\text { April }\end{array}$ & 2002-2003 & $20 \times 20$ & $\begin{array}{l}\text { SC; } \\
\text { Spec }\end{array}$ & $\begin{array}{l}\text { Brito et al., } \\
2013\end{array}$ \\
\hline Chl-a & Daebu mudflat & South Korea & $37^{\circ} 12^{\prime} \mathrm{N}$ & Mud & March & January & - & - & Monthly & 2008-2010 & $-(1)$ & $\begin{array}{l}\text { SC; } \\
\text { Spec }\end{array}$ & $\begin{array}{l}\text { Kwon et al., } \\
2018\end{array}$ \\
\hline Chl-a & $\begin{array}{l}\text { Inner Cadiz } \\
\text { Bay. PR } \\
\text { Transect }\end{array}$ & Spain & $36^{\circ} 30^{\prime} \mathrm{N}$ & Mud & January & $\begin{array}{l}\text { July; } \\
\text { October }\end{array}$ & $\begin{array}{l}\text { Upper } \\
\text { (except in } \\
\text { January) }\end{array}$ & $\begin{array}{l}\text { Lower } \\
\text { (except in } \\
\text { January) }\end{array}$ & Quarterly & 2016-2017 & $420(5)$ & $\begin{array}{l}\text { SC; } \\
\text { Spec }\end{array}$ & This study \\
\hline
\end{tabular}


TABLE 3 | Continued

\begin{tabular}{|c|c|c|c|c|c|c|c|c|c|c|c|c|c|}
\hline \multirow[t]{2}{*}{ Variable } & \multicolumn{4}{|c|}{ Estuary characteristics } & \multicolumn{2}{|c|}{ Seasonal variability } & \multicolumn{2}{|c|}{ Spatial variability } & \multicolumn{2}{|c|}{ Temporal resolution } & \multirow{2}{*}{$\begin{array}{l}\begin{array}{l}\text { Spatial } \\
\text { resolution }\end{array} \\
\text { Grid or } \\
\text { Transect } \\
\text { length (m) } \\
\text { (Numbers } \\
\text { of sampling } \\
\text { stations) }\end{array}$} & \multirow{2}{*}{$\begin{array}{l}\text { Analysis } \\
\text { method }\end{array}$} & \multirow[t]{2}{*}{ References } \\
\hline & Estuary & Country & Latitude & Substrate & Maximum & Minimum & Maximum & Minimum & & & & & \\
\hline Chl-a & $\begin{array}{l}\text { Inner Cadiz } \\
\text { Bay. SF } \\
\text { Transect }\end{array}$ & Spain & $36^{\circ} 28^{\prime} \mathrm{N}$ & $\begin{array}{l}\text { Muddy- } \\
\text { sandy }\end{array}$ & January & $\begin{array}{l}\text { April; } \\
\text { October }\end{array}$ & Middle & Upper & Quarterly & 2016-2017 & $450(5)$ & $\begin{array}{l}\text { SC; } \\
\text { Spec }\end{array}$ & This study \\
\hline Chl-a & Inner Cadiz Bay & Spain & $36^{\circ} 31^{\prime} \mathrm{N}$ & Mud & January & April & - & - & Monthly & 2008 & $-(1)$ & $\begin{array}{l}\text { SC; } \\
\text { Spec }\end{array}$ & $\begin{array}{l}\text { Garcia- } \\
\text { Robledo } \\
\text { et al., } 2016\end{array}$ \\
\hline Chl-a & $\begin{array}{l}\text { Gwanghwal__ } \\
\text { Saemangeum }\end{array}$ & South Korea & $35^{\circ} 30^{\prime} \mathrm{N}$ & $\begin{array}{l}\text { Muddy- } \\
\text { sand }\end{array}$ & $\begin{array}{l}\text { Winter- } \\
\text { Spring }\end{array}$ & $\begin{array}{l}\text { Summer- } \\
\text { Fall }\end{array}$ & Upper & Lower & Monthly & 2004 & $\begin{array}{l}30 \times 30 \\
(33)\end{array}$ & $\begin{array}{l}\text { RS; } \\
\text { SC; } \\
\text { Spec }\end{array}$ & $\begin{array}{l}\text { Kwon et al., } \\
2016\end{array}$ \\
\hline Chl-a & $\begin{array}{l}\text { Gyehwa_ } \\
\text { Saemangeum } \\
\text { flat }\end{array}$ & South Korea & $35^{\circ} 30^{\prime} \mathrm{N}$ & $\begin{array}{l}\text { Muddy- } \\
\text { sand }\end{array}$ & $\begin{array}{l}\text { Winter- } \\
\text { Spring }\end{array}$ & Fall & $\begin{array}{l}\text { Upper- } \\
\text { middle }\end{array}$ & Lower & Monthly & 2004 & $\begin{array}{l}30 \times 30 \\
(64)\end{array}$ & $\begin{array}{l}\text { RS; } \\
\text { SC; } \\
\text { Spec }\end{array}$ & $\begin{array}{l}\text { Kwon et al., } \\
2016\end{array}$ \\
\hline Chl-a & $\begin{array}{l}\text { Isshiki flat, } \\
\text { Mikawa Bay }\end{array}$ & Japan & $34^{\circ} 46^{\prime} \mathrm{N}$ & Mud & Apri & October & - & - & Monthly & 1997-1998 & $\begin{array}{l}500 \text { (5) and } \\
290 \text { (3) }\end{array}$ & $\begin{array}{l}\text { SC; } \\
\text { Spec }\end{array}$ & $\begin{array}{l}\text { Goto et al., } \\
2000\end{array}$ \\
\hline Chl-a & $\begin{array}{l}\text { Nanaura } \\
\text { mudflat, Ariake } \\
\text { Sea }\end{array}$ & Japan & $33^{\circ} 00^{\prime} \mathrm{N}$ & Mud & February & July & - & - & $\begin{array}{l}\text { Every 2-3 } \\
\text { weeks }\end{array}$ & 2002-2003 & $-(1)$ & $\begin{array}{l}\text { SC; } \\
\text { Spec }\end{array}$ & $\begin{array}{l}\text { Koh et al., } \\
2007\end{array}$ \\
\hline \multicolumn{14}{|l|}{$\begin{array}{l}\text { Primary } \\
\text { production }\end{array}$} \\
\hline$P_{G}$ & $\begin{array}{l}\text { Bay of Somme, } \\
\text { English } \\
\text { Channel }\end{array}$ & France & $50^{\circ} 13^{\prime} \mathrm{N}$ & Sandy & June & February & - & - & Quarterly & 2001-2002 & - & $\mathrm{BC}$ & $\begin{array}{l}\text { Migné et al., } \\
2004\end{array}$ \\
\hline$P_{G}$ & $\begin{array}{l}\text { Roscoff Aber } \\
\text { Bay }\end{array}$ & France & $48^{\circ} 42^{\prime} \mathrm{N}$ & $\begin{array}{l}\text { Muddy- } \\
\text { coarse }\end{array}$ & August & February & $\begin{array}{l}\text { Upper- } \\
\text { middle }\end{array}$ & Lower & Monthly & 2003-2004 & 2000 (3) & $\mathrm{BC}$ & $\begin{array}{l}\text { Hubas et al., } \\
2006\end{array}$ \\
\hline$P_{G}$ & $\begin{array}{l}\text { Mont } \\
\text { Saint-Michal } \\
\text { Bay. Ca } \\
\text { Transect }\end{array}$ & France & $48^{\circ} 35^{\prime} \mathrm{N}$ & Mud & August & February & Middle & Lower & Quarterly & 2003-2004 & 2000 (3) & $\mathrm{BC}$ & $\begin{array}{l}\text { Davoult et al., } \\
2009\end{array}$ \\
\hline$P_{G}$ & $\begin{array}{l}\text { Mont } \\
\text { Saint-Michel } \\
\text { Bay. Ch } \\
\text { Transect }\end{array}$ & France & $48^{\circ} 35^{\prime} \mathrm{N}$ & Sand & $\begin{array}{l}\text { April- } \\
\text { August }\end{array}$ & February & Middle & Lower & Quarterly & 2003-2004 & 2500 (3) & $\mathrm{BC}$ & $\begin{array}{l}\text { Davoult et al., } \\
2009\end{array}$ \\
\hline$P_{N}$ & $\begin{array}{l}\text { Brouage } \\
\text { mudflat }\end{array}$ & France & $45^{\circ} 54^{\prime} \mathrm{N}$ & Mud & Spring & Fall & - & - & $\begin{array}{l}\text { February \& } \\
\text { July; April, } \\
\text { July \& } \\
\text { November; } \\
\text { February \& } \\
\text { April }\end{array}$ & $\begin{array}{l}\text { 2008; } \\
\text { 2012; } 2013\end{array}$ & $250 \times 250$ & $\begin{array}{l}\text { RS; } \\
\text { model }\end{array}$ & $\begin{array}{l}\text { Savelli et al., } \\
2018\end{array}$ \\
\hline
\end{tabular}


TABLE 3 | Continued

\begin{tabular}{|c|c|c|c|c|c|c|c|c|c|c|c|c|c|}
\hline \multirow[t]{2}{*}{ Variable } & \multicolumn{4}{|c|}{ Estuarycharacteristics } & \multicolumn{2}{|c|}{ Seasonal variability } & \multicolumn{2}{|c|}{ Spatial variability } & \multicolumn{2}{|c|}{ Temporal resolution } & \multirow{2}{*}{$\begin{array}{l}\begin{array}{l}\text { Spatial } \\
\text { resolution }\end{array} \\
\text { Grid or } \\
\text { Transect } \\
\text { length (m) } \\
\text { (Numbers } \\
\text { of sampling } \\
\text { stations) }\end{array}$} & \multirow{2}{*}{$\begin{array}{l}\text { Analysis } \\
\text { method }\end{array}$} & \multirow[t]{2}{*}{ References } \\
\hline & Estuary & Country & Latitude & Substrate & Maximum & Minimum & Maximum & Minimum & & & & & \\
\hline $\mathrm{P}_{\mathrm{N}}$ & Daebu mudflat & South Korea & $37^{\circ} 12^{\prime} \mathrm{N}$ & Mud & April & January & - & - & Monthly & 2008-2010 & $-(1)$ & $\begin{array}{l}\text { SC; } \\
\text { OxM }\end{array}$ & $\begin{array}{l}\text { Kwon et al., } \\
2018\end{array}$ \\
\hline$P_{N}$ & Inner Cadiz Bay & Spain & $36^{\circ} 31^{\prime} \mathrm{N}$ & Mud & July & January & - & - & Monthly & 2008 & $-(1)$ & $\begin{array}{l}\text { SC; } \\
\text { OxM }\end{array}$ & $\begin{array}{l}\text { Garcia- } \\
\text { Robledo } \\
\text { et al., } 2016\end{array}$ \\
\hline$P_{N}$ & $\begin{array}{l}\text { Inner Cadiz } \\
\text { Bay. PR } \\
\text { Transect }\end{array}$ & Spain & $36^{\circ} 30^{\prime} \mathrm{N}$ & Mud & January & $\begin{array}{l}\text { July; } \\
\text { October }\end{array}$ & $\begin{array}{l}\text { Upper } \\
\text { (except in } \\
\text { January) }\end{array}$ & $\begin{array}{l}\text { Lower } \\
\text { (except to } \\
\text { January) }\end{array}$ & Quarterly & 2016-2017 & $420(5)$ & $\begin{array}{l}\text { SC; } \\
\text { OxM }\end{array}$ & This study \\
\hline $\mathrm{P}_{\mathrm{N}}$ & $\begin{array}{l}\text { Inner Cadiz } \\
\text { Bay. SF } \\
\text { Transect }\end{array}$ & Spain & $36^{\circ} 28^{\prime} \mathrm{N}$ & $\begin{array}{l}\text { Muddy- } \\
\text { sandy }\end{array}$ & January & April & Middle & $\begin{array}{l}\text { Lower } \\
\text { (Caulerpa } \\
\text { prolifera) }\end{array}$ & Quarterly & 2016-2017 & $450(5)$ & $\begin{array}{l}\text { SC; } \\
\text { OxM }\end{array}$ & This study \\
\hline$P_{G}$ & $\begin{array}{l}\text { Isshiki flat, } \\
\text { Mikawa Bay }\end{array}$ & Japan & $34^{\circ} 46^{\prime} \mathrm{N}$ & Mud & $\begin{array}{l}\text { February- } \\
\text { March }\end{array}$ & August & - & - & Monthly & 1997-1998 & $\begin{array}{l}500(5) \text { and } \\
290(3)\end{array}$ & ${ }^{14} \mathrm{C}$ & $\begin{array}{l}\text { Goto et al., } \\
2000\end{array}$ \\
\hline \multicolumn{14}{|l|}{ Respiration } \\
\hline $\mathrm{R}_{\mathrm{D}}$ & $\begin{array}{l}\text { Roscoff Aber } \\
\text { Bay }\end{array}$ & France & $48^{\circ} 42^{\prime} \mathrm{N}$ & $\begin{array}{l}\text { Muddy- } \\
\text { coarse }\end{array}$ & July & February & Upper & Lower & Monthly & 2003-2004 & $2000(3)$ & $\mathrm{BC}$ & $\begin{array}{l}\text { Hubas et al., } \\
2006\end{array}$ \\
\hline $\mathrm{R}_{\mathrm{D}}$ & $\begin{array}{l}\text { Mont } \\
\text { Saint-Michal } \\
\text { Bay. Ca } \\
\text { Transect }\end{array}$ & France & $48^{\circ} 35^{\prime} \mathrm{N}$ & Mud & April & August & Lower & Upper & Quarterly & 2003-2004 & $2000(3)$ & $\mathrm{BC}$ & $\begin{array}{l}\text { Davoult et al., } \\
2009\end{array}$ \\
\hline $\mathrm{R}_{\mathrm{D}}$ & $\begin{array}{l}\text { Mont } \\
\text { Saint-Michel } \\
\text { Bay. Ch } \\
\text { Transect }\end{array}$ & France & $48^{\circ} 35^{\prime} \mathrm{N}$ & Sand & April & August & - & - & Quarterly & 2003-2004 & $2500(3)$ & $\mathrm{BC}$ & $\begin{array}{l}\text { Davoult et al., } \\
2009\end{array}$ \\
\hline $\mathrm{R}_{\mathrm{D}}$ & Inner Cadiz Bay & Spain & $36^{\circ} 31^{\prime} \mathrm{N}$ & Mud & April & January & - & - & Monthly & 2008 & $-(1)$ & $\begin{array}{l}\text { SC; } \\
\text { OxM }\end{array}$ & $\begin{array}{l}\text { Garcia- } \\
\text { Robledo } \\
\text { et al., } 2016\end{array}$ \\
\hline $\mathrm{R}_{\mathrm{D}}$ & $\begin{array}{l}\text { Inner Cadiz } \\
\text { Bay. PR } \\
\text { Transect }\end{array}$ & Spain & $36^{\circ} 30^{\prime} \mathrm{N}$ & Mud & April & October & Middle & Lower & Quarterly & 2016-2017 & $420(5)$ & $\begin{array}{l}\text { SC; } \\
\text { OxM }\end{array}$ & This study \\
\hline $\mathrm{R}_{\mathrm{D}}$ & $\begin{array}{l}\text { Inner Cadiz } \\
\text { Bay. SF } \\
\text { Transect }\end{array}$ & Spain & $36^{\circ} 28^{\prime} \mathrm{N}$ & $\begin{array}{l}\text { Muddy- } \\
\text { sandy }\end{array}$ & April & $\begin{array}{l}\text { October; } \\
\text { January }\end{array}$ & Lower & Upper & Quarterly & 2016-2017 & $450(5)$ & $\begin{array}{l}\text { SC; } \\
\text { OxM }\end{array}$ & This study \\
\hline
\end{tabular}

MSL, mean sea level; RS, remote sensing; Spec, Chl-a spectrophotometric analysis; SC, sediment cores; BC, benthic chamber; OxM, oxygen microelectrodes. 
these stations due to the protection macrophytes provide to associated microalgal communities against resuspension (Lemley et al., 2017). In addition, the upper shore sediment at this transect was sandier and had a higher MSL $(1.7 \mathrm{~m})$, meaning longer emersion periods and faster draining (Dye, 1980). As a result, desiccation and temperature effects would be stronger in the upper shore. Various authors have reported higher MPB biomass in the middle-upper shore along the intertidal (Table 3) (Davoult et al., 2009; Benyoucef et al., 2013). Underwood (2001) suggested that the MPB distribution along the intertidal could show a peak somewhere between mid-tide and mean high water neap tide level (stations SF3 and SF4 in our transect), and not necessarily at the upper shore. This range of the intertidal offers optimum conditions for MPB growth; lower hydrodynamic conditions (i.e., lower resuspension compared with the lower shore) and reduced desiccation and irradiance effects, compared to the high shore. The mixed sediment type transect (SF) showed such a distribution, with MPB biomass even higher than PR in the intermediate stations. Overall, our data indicate that the spatial distribution of MPB along the intertidal is highly variable and site specific and that other methods such as remote sensing should be used to estimate spatial patterns in the bay due to the high spatial heterogeneity.

\section{Sediment Primary Production and Respiration Along the Intertidal Gradient}

Spatial and temporal patterns of $\mathrm{P}_{\mathrm{N}}$ are not frequently studied. Instead, MPB biomass is used as a proxy for $\mathrm{P}_{\mathrm{N}}$ given that the former can be estimated by a more direct and relatively fast technique (i.e., remote sensing). However, the conversion of MPB biomass to primary production values is not straightforward (Daggers et al., 2018; Méléder et al., 2018; Savelli et al., 2018), so direct measurements with oxygen microelectrodes or ${ }^{14} \mathrm{C}$ are essential (Brotas et al., 2003; Garcia-Robledo et al., 2016; Walpersdorf et al., 2017). In Cadiz Bay, $\mathrm{P}_{\mathrm{N}}$ rates determined using microelectrodes were always positive in the PR transect and in the majority of the cases at the first four stations of the SF transect indicating an autotrophic community. However, at SF5, where C. prolifera meadows are present, sediment metabolism was net heterotrophic all year round. In the $\mathrm{PR}$ transect, $\mathrm{P}_{\mathrm{N}}$ rates were surprisingly rather homogeneous during most of the year, with the exception of January, when they were three times higher and slightly increased downshore. In the SF transect, $\mathrm{P}_{\mathrm{N}}$ rates exhibited a similar pattern for the above zero MSL stations of a slight increase toward the mid intertidal (with the exception of April when surprisingly the opposite was observed) coinciding with muddier sediments in the middle of the intertidal.

At the SF transect, the variables selected during the statistical analysis could explain only $25 \%$ of the variability in $\mathrm{P}_{\mathrm{N}}$. This is probably due to the larger variability and non-linear patterns in terms of gradient slope, vegetation type, and grain size distribution-and correlated variables, such as OC and porewater nutrient content-in SF compared to PR. The variables that explained better the pattern of $\mathrm{P}_{\mathrm{N}}$ in $\mathrm{SF}$ were $\mathrm{Chl} c$ and PC1. The latter was composed principally by geo-morphological variables (MSL, shore distance, grain size, and porosity), OC, and porewater nutrients (Tables 1, 2), highlighting the importance of the spatial variability along the SF transect (Figure 6). At this location, grain size distribution was negatively correlated to MSL $(r=-0.838)$ and therefore it is difficult to discern between the two predictors. However, Orvain et al. (2012) reported that, in the macro-intertidal des Veys Bay (France), MPB biomass variability was mainly explained by grain size, whereas MSL only explained 2-3\%. Likewise, Daggers et al. (2018) considered grain size distribution as one of the most important variables to predict $\mathrm{P}_{\mathrm{N}}$ in the tidal environments of Oosterschelde and Westerschelde (Netherlands). In contrast, Hubas et al. (2006) determined that neither porewater nutrients, which in SF contributed to explain $\mathrm{P}_{\mathrm{N}}$, nor grain size controlled MPB net metabolism along a granulometric gradient in an intertidal area in the Roscoff Aber Bay (France). Instead, Hubas et al. (2006) determined that net metabolism of MPB was mainly controlled by temperature. However, in our case, when $\mathrm{P}_{\mathrm{N}}$ were corrected for $\mathrm{Q}_{10}$ (Supplementary Figure 2), no differences were found in the spatio-temporal patterns. Lastly, the inclusion of Chl $c$, a characteristic pigment of benthic diatoms, among the variables best explaining MPB $\mathrm{P}_{\mathrm{N}}$ corroborates that measured $\mathrm{P}_{\mathrm{N}}$ rates with the microelectrodes were not affected by macrophytes but were a direct result of the MPB community production (mainly diatoms).

In $\mathrm{PR}$, in contrast to $\mathrm{SF}$, the selected model could explain a high percentage of $\mathrm{P}_{\mathrm{N}}$ variability $(60 \%)$. Sediment-related variables (e.g., grain size, porewater nutrients, organic matter) were more homogenous both in time and space and thus were not expected to contribute significantly in explaining the differences observed in metabolic rates. Indeed, the PC that explain the patterns in $\mathrm{P}_{\mathrm{N}}$ was composed of meteorological variables (irradiance and temperature), OC, and water column nutrients (Tables 1, 2). This highlights the strong effect seasonal acclimation of the MPB community has in these muddy sediments, and this despite the fact that the experimental conditions we used were the same year-round (saturating irradiance and constant temperature). Of course, other biotic, i.e., grazing, or physical factors, i.e., current speed, that were not studied in this work have also been proposed to explain $\mathrm{P}_{\mathrm{N}}$ variability (Hubas et al., 2006; Van der Wal et al., 2008; Savelli et al., 2018). Their importance remains to be tested for the Cadiz Bay and could contribute to better explaining the spatial variability of $\mathrm{P}_{\mathrm{N}}$ with respect to MSL.

Diel and seasonal variability also exists for $\mathrm{R}_{\mathrm{D}}$ (Davoult et al., 2009) although this tends to be less pronounced than the one for $\mathrm{P}_{\mathrm{N}} \cdot \mathrm{R}_{\mathrm{D}}$ rates usually remain constant throughout the dark period for several days in laboratory experiments (Haro et al., 2019). In addition, preliminary experiments in microcosms with Cadiz Bay sediment found no substantial differences between $\mathrm{R}_{\mathrm{D}}$ in emersion and immersion. However, in situ daily variations due to changes in tidal conditions have been reported elsewhere (Migné et al., 2009). Seasonality of $\mathrm{R}_{\mathrm{D}}$ rates is mainly controlled by (1) temperature (Migné et al., 2004) and (2) variations in the activity of heterotrophic bacteria (which might explain up to $88 \%$ of sediment respiration, Hubas et al., 2006), with highest rates being expected in summer. Surprisingly, in Cadiz Bay, the highest rates were found in January in PR and April in SF (Figure 5C). 
However, when correcting $\mathrm{R}_{\mathrm{D}}$ rates for the temperature in situ (Supplementary Figure 2) (Hancke and Glud, 2004; Migné et al., 2004; Kwon et al., 2018), in both transects highest $\mathrm{R}_{\mathrm{D}}$ rates were still found in spring, not in summer. On the one hand, this is probably due to a higher availability of labile OC in spring after the MPB and macroalgal blooms and on the other, to the high sediment temperatures in summer which can reach well above $30^{\circ} \mathrm{C}$ (Guarini et al., 1997), affecting negatively the resident microbial community which tends to show an optimum between 25-30 ${ }^{\circ} \mathrm{C}$ (Thamdrup et al., 1998).

Regression analysis indicated that the variables that best explained $R_{D}$ rates in the PR transect (41\%) included the PC axes composed of principally of nutrients in the water column and the sediment. In contrast, in SF, the variables selected were the PC axes that were composed mainly of MSL, grain size gradient, OC, and porewater nutrient content, as well as some meteorological aspects (wind and rain), all of which explained $25 \%$ of the variation in $\mathrm{R}_{\mathrm{D}}$ rates. The cause-effect relationship between $R_{D}$ rates and the selected variables is not always clear and should be treated with caution. For example, OC carbon content was highly related to both grain size and MSL in SF; clearly, it is the higher OC availability in the sediment that can stimulate higher $\mathrm{R}_{\mathrm{D}}$ rates. On the other hand, $\mathrm{R}_{\mathrm{D}}$ rates did not reflect the significant differences observed in the OC content between the stations along the transect which was four to five times lower in the sandy compared to the muddy stations (Figure 3A). In the case of the nutrient concentrations, either in the water column or the porewater, the relationship can be bidirectional; higher $\mathrm{R}_{\mathrm{D}}$ rates would result in increased mineralization rates and higher nutrient release to the sediment and porewater, while at the same time, higher nutrient concentrations can stimulate the growth of microorganisms, especially ones using anaerobic mineralization pathways, and thus the overall sediment metabolism (Canfield et al., 2005).

\section{Contribution of PP $\mathrm{MPB}_{\mathrm{MP}}$ to Total Benthic Production in Cadiz Bay Intertidal Sediments}

The intertidal sediment in the inner Cadiz Bay is principally muddy with only $10 \%$ sandy areas (Sanchez De Lamadrid Rey and Muñoz Pérez, 1994). The annual rate of $P_{N}$ in light for bare intertidal muddy sediment in the inner Cadiz bay was $105.8 \mathrm{~g}$ $\mathrm{C} \mathrm{m}^{-2}$ year $^{-1}$, which is similar to that calculated for other estuaries with muddy sediment in southern Europe, e.g., $156 \mathrm{~g}$ $\mathrm{C} \mathrm{m}^{-2}$ year $^{-1}$ for the Tagus Estuary in Portugal (Serôdio and Catarino, 2000) and $127 \mathrm{~g} \mathrm{C} \mathrm{m}^{-2}$ year $^{-1}$ for the Brouage mudflat in France (Savelli et al., 2018). The annual net metabolism for bare intertidal muddy sediment in inner Cadiz Bay was net autotrophic (73.3 $\mathrm{g} \mathrm{C} \mathrm{m}^{-2}$ year ${ }^{-1}$ ). This was higher than that measured in other temperate estuaries; $25 \mathrm{~g} \mathrm{C} \mathrm{m}^{-2}$ year $^{-1}$ in the Seine Estuary (Migné et al., 2004), or even negative, $-41 \mathrm{~g}$ $\mathrm{C} \mathrm{m}^{-2}$ year $^{-1}$ in the Bay of Somme and $-78 \mathrm{~g} \mathrm{C} \mathrm{m}^{-2}$ year $^{-1}$ in Mont Saint-Michel Bay, both on the English Channel in France (Spilmont et al., 2006; Migné et al., 2009). These mudflats exhibited annual $\mathrm{R}_{\mathrm{D}}$ rates higher than the $32.5 \mathrm{~g} \mathrm{C} \mathrm{m}^{-2}$ year $^{-1}$ measured in our study. In bare sandy sediments in the inner Cadiz Bay, the annual net metabolism was lower, 29.6 g C $\mathrm{m}^{-2}$ year $^{-1}$. In the Roscoff Aber Bay, in France, an autotrophic annual metabolism of up to $16 \mathrm{~g} \mathrm{C} \mathrm{m}^{-2}$ year $^{-1}$ at the sandy sediments was reported by Hubas and Davoult (2006).

The intertidal area of the inner Cadiz Bay covers $\sim 60 \%$ of its surface $\left(13 \mathrm{~km}^{2}\right.$, Sanchez De Lamadrid Rey and Muñoz Pérez, 1994). Of that, approximately $70 \%$ is covered by the seagrass $Z$. noltei and the remaining is bare sediment covered by MPB and occasionally green macroalgae (Gómez Ordoñez, 2008). According to the extracted values from grain size distribution maps (Sanchez De Lamadrid Rey and Muñoz Pérez, 1994), approximately $90 \%$ of the bare sediment in the inner Cadiz Bay is muddy. When the differences in vegetation and sediment type cover are taken into account, the annual net metabolism of MPB for bare sediment is 285.9 t C year $^{-1}$ (257.3 and $10.4 \mathrm{t} \mathrm{C} \mathrm{year}^{-1}$ for muddy and sandy sediments, respectively), whereas for the sandy-muddy sediment covered by $Z$. noltei, the contribution of MPB, based on the data from sampling stations SF3 and SF4 in SF, is $177.2 \mathrm{t} \mathrm{C}$ year $^{-1}$. Thus, the total annual metabolism attributed to intertidal MPB is $444.9 \mathrm{t} \mathrm{C}$ year $^{-1}$.

In order to calculate the MPB contribution to the total benthic production in intertidal sediments in the inner Cadiz Bay, we estimated the production of $Z$. noltei. Previous studies in the area have estimated the total annual production of $Z$. noltei in the Los Toruños area of Cadiz Bay to be $51 \mathrm{~g} \mathrm{C} \mathrm{m}^{-2}$ year $^{-1}$ (Brun et al., 2003), corresponding to an annual production for the entire bay of $464.1 \mathrm{t} \mathrm{C}$ year $^{-1}$. Therefore, $48.9 \%$ of the total intertidal benthic primary production would correspond to MPB. Similarly, Asmus and Asmus (2000) estimated that MPB production contributes up to $54 \%$ of the total primary production on an intertidal Zostera bed in the Wadden Sea, $347 \mathrm{~g}$ $\mathrm{C} \mathrm{m}^{-2}$ year $^{-1} \mathrm{MPB}$ production vs. $258 \mathrm{~g} \mathrm{C} \mathrm{m}^{-2}$ year $^{-1}$ for Zostera. Therefore, our data confirm the important contribution of MPB to the total primary production in coastal shallow systems (Underwood and Kromkamp, 1999) even in the presence of important primary producers such as seagrass meadows.

\section{CONCLUSION}

Our results suggest that the seasonal and spatial variability of MPB biomass and $\mathrm{MPB} \mathrm{P}_{\mathrm{N}}$ in different locations within the same system can be affected by different sets of environmental factors. This variability makes producing good PP predictive models with general applicability to different environments very difficult. Nonetheless, from system intercomparison, it seems that seasonal and spatial patterns of $\mathrm{MPB} \mathrm{P}_{\mathrm{N}}$ along the intertidal seem to depend on latitudinal conditions of daylight irradiance and temperature and on substrate type, the latter being strongly related with the hydrodynamic conditions in the zone in question. Clearly, more work, combining laboratory experiments and field studies, is needed to disentangle the relationships between MPB biomass and net metabolism and the rather high number of environmental variables that have been used to explain the standing stock of MPB and its biological activity in the intertidal zone. Most of these variables change at different spatiotemporal scales, complicating further the investigation on their role on MPB patterns. New techniques, such as the aquatic eddy correlation technique or in situ continuous oxygen profiling, 
will allow exploring long-term changes of $\mathrm{PP}_{\mathrm{MPB}}$ in situ with non-destructive techniques. This, in addition to the progress in remote sensing with the increasing availability of satellite images of increased quality and resolution, will aid in estimating with higher precision $\mathrm{PP}_{\mathrm{MPB}}$ and its contribution to estuarine primary production.

\section{DATA AVAILABILITY STATEMENT}

The datasets are available on request. The raw data supporting the conclusions of this article will be made available by the authors, without undue reservation, to any qualified researcher.

\section{AUTHOR CONTRIBUTIONS}

All authors were involved in the study design. ML, IL, and CG selected the sampling stations. $\mathrm{SH}, \mathrm{ML}$, and $\mathrm{AC}$ carried out the samplings. SH and ML conducted the measurements. SH, ML,

\section{REFERENCES}

Asmus, H., and Asmus, R. (2000). Material exchange and food web of seagrass beds in the Sylt-Rømø Bight: how significant are community changes at the ecosystem level? Helgol. Mar. Res. 54, 137-150. doi: 10.1007/s101520050012

Balsam, W. L., Deaton, B. C., and Damuth, J. E. (1998). The effects of water content on diffuse reflectance spectrophotometry studies of deep-sea sediment cores. Mar. Geol. 149, 177-189. doi: 10.1016/s0025-3227(98)00033-4

Barranguet, C., Kromkamp, J., and Peene, J. (1998). Factors controlling primary production and photosynthetic characteristics of intertidal microphytobenthos. Mar. Ecol. Prog. Ser. 173, 117-126. doi: 10.3354/meps 173117

Barrón, C., Middelburg, J. J., and Duarte, C. M. (2006). Phytoplankton trapped within seagrass (Posidonia oceanica) sediments are a nitrogen source: an in situ isotope labeling experiment. Limnol. Oceanogr. 51, 1648-1653. doi: 10.4319/lo. 2006.51.4.1648

Benyoucef, I., Blandin, E., Lerouxel, A., Jesus, B., Rosa, P., Méléder, V., et al. (2013). Microphytobenthos interannual variations in a North-European estuary (Loire estuary, France) detected by visible-infrared multispectral remote sensing. Estuar. Coast. Shelf Sci. 136, 43-52. doi: 10.1016/j.ecss.2013.11.007

Bohórquez, J., Calenti, D., Garcia-Robledo, E., Papaspyrou, S., Jimenez-Arias, J. L., Gómez-Ramírez, E. H., et al. (2019). Water column dissolved silica concentration limits microphytobenthic primary production in intertidal sediments. J. Phycol. 55, 625-636. doi: 10.1111/jpy.12838

Bohórquez, J., Papaspyrou, S., Yúfera, M., Van Bergeijk, S. A., Garcia-Robledo, E., Jimenez-Arias, J. L., et al. (2013). Effects of green macroalgal blooms on the meiofauna community structure in the Bay of Cadiz. Mar. Pollut. Bull. 70, 10-17. doi: 10.1016/j.marpolbul.2013.02.002

Brito, A., Benyoucef, I., Jesus, B., Brotas, V., Gernez, P., Mendes, C. R., et al. (2013). Seasonality of microphytobenthos revealed by remote-sensing in a South European estuary. Cont. Shelf Res. 66, 83-91. doi: 10.1016/j.csr.2013. 07.004

Brotas, V., Serôdio, J., Risgaard-Petersen, N., Dalsgaard, T., Serôdio, J., Ottosen, L., et al. (2003). In situ measurements of photosynthetic activity and respiration of intertidal benthic microalgal communities undergoing vertical migration. Ophelia 57, 13-26. doi: 10.1080/00785236.2003.10409502

Brun, F. G., Pérez-Lloréns, J. L., Hernández, I., and Vergara, J. J. (2003). Patch Distribution and Within-Patch Dynamics of the Seagrass Zostera noltii Hornem. in Los Toruños Salt-Marsh. Cadiz Bay, Natural Park, Spain. Bot. Mar. 46, 513-524. doi: 10.1515/BOT.2003.053

Brun, F. G., Vergara, J. J., and Morris, E. P. (2015). Diversidad de angiospermas marinas en la bahía de Cádiz: redescubriendo a Zostera marina. Chron. Naturae $5,45-56$. and SP participated in the statistical analysis of the data. All authors contributed to data interpretation. SH, ML, AC, and SP wrote the manuscript. All authors contributed to the manuscript revision and approved the final submitted version.

\section{FUNDING}

This study was supported by the Spanish Ministry of Economy and Business (MINECO) through the projects MICROBAHIA and MICROBAHIA2 (CTM2013-43857-R and CTM2017-82274-R) awarded to AC. SH was funded by a Ph.D. fellowship from the University of Cádiz, Spain.

\section{SUPPLEMENTARY MATERIAL}

The Supplementary Material for this article can be found online at: https://www.frontiersin.org/articles/10.3389/fmars. 2020.00039/full\#supplementary-material

Buchanan, J. B. (1984). “Sediment analysis", in Methods for the Study of Marine Benthos, eds N. A. Holme, and A. D. McIntyre, (London: Blackwell Scientific Publications), 41-64.

Canfield, D. E., Thamdrup, B., and Kristensen, E. (2005). "Aquatic Geomicrobiology," in Advances in Marine Biology. Cambridge, MA: Elsevier Academic Press.

Cariou-Le Gall, V., and Blanchard, G. F. (1995). Concentration from an intertidal muddy sediment. Mar. Ecol. Prog. Ser. 121, 171-179. doi: 10.3354/meps121171

Carrasco, M., López-Ramírez, J. A., Benavente, J., López-Aguayo, F., and Sales, D. (2003). Assessment of urban and industrial contamination levels in the bay of Cadiz. SW Spain. Mar. Pollut. Bull. 46, 335-345. doi: 10.1016/S0025-326X(02) 00420-4

Chisholm, J. R. M., and Moulin, P. (2003). Stimulation of nitrogen fixation in refractory organic sediments by Caulerpa taxifolia (Chlorophyta). Limnol. Oceanogr. 48, 787-794. doi: 10.4319/lo.2003.48.2.0787

Cho, K. H., Kang, J.-H., Ki, S. J., Park, Y., Cha, S. M., and Kim, J. H. (2009). Determination of the optimal parameters in regression models for the prediction of chlorophyll-a: A case study of the Yeongsan Reservoir. Korea. Sci. Total Environ. 407, 2536-2545. doi: 10.1016/j.scitotenv.2009. 01.017

Cibic, T., Blasutto, O., Falconi, C., and Fonda Umani, S. (2007). Microphytobenthic biomass, species composition and nutrient availability in sublittoral sediments of the Gulf of Trieste (northern Adriatic Sea). Estuar. Coast. Shelf Sci. 75, 50-62. doi: 10.1016/j.ecss.2007.01.020

Coelho, H., Cartaxana, P., Brotas, V., Queiroga, H., and Serôdio, J. (2011). Pheophorbide $a$ in Hydrobia ulvae faecal pellets as a measure of microphytobenthos ingestion: variation over season and period of day. Aquat. Biol. 13, 119-126. doi: 10.3354/ab00356

Coelho, H., Vieira, S., and Serôdio, J. (2009). Effects of desiccation on the photosynthetic activity of intertidal microphytobenthos biofilms as studied by optical methods. J. Exp. Mar. Bio. Ecol. 381, 98-104. doi: 10.1016/j.jembe.2009. 09.013

Colijn, F., and De Jonge, V. N. (1984). Primary production of microphytobenthos in the Ems-Dollard Estuary. Mar. Ecol. Prog. Ser. 14, 185-196. doi: 10.3354/ meps014185

Daggers, T. D., Kromkamp, J., Herman, P. M. J., and van der Wal, D. (2018). A model to assess microphytobenthic primary production in tidal systems using satellite remote sensing. Remote Sens. Environ. 211, 129-145. doi: 10.1016/j.rse. 2018.03.037

Davoult, D., Migné, A., Créach, A., Gévaert, F., Hubas, C., Spilmont, N., et al. (2009). Spatio-temporal variability of intertidal benthic primary production and respiration in the western part of the Mont Saint-Michel Bay (Western English 
Channel. France). Hydrobiologia 620, 163-172. doi: 10.1007/s10750-0089626-3

De Jonge, V. N. (1980). Fluctuations in the organic carbon to chlorophyll a ratios for estuarine benthic diatom populations. Mar. Ecol. Prog. Ser. 2, 345-353. doi: $10.3354 /$ meps 002345

Dye, A. H. (1980). Tidal fluctuations in biological oxygen demand in exposed sandy beaches. Estuar. Coast. Mar. Sci. 11, 1-8. doi: 10.1016/S0302-3524(80)80024-7

Garcia-Robledo, E., Bohórquez, J., Corzo, A., Jimenez-Arias, J. L., and Papaspyrou, S. (2016). Dynamics of inorganic nutrients in intertidal sediments: porewater, exchangeable, and intracellular pools. Front. Microbiol. 7:761. doi: 10.3389/ fmicb.2016.00761

Garcia-Robledo, E., Corzo, A., García De Lomas, J., and van Bergeijk, S. A. (2008). Biogeochemical effects of macroalgal decomposition on intertidal microbenthos: a microcosm experiment. Mar. Ecol. Prog. Ser. 356, 139-151. doi: 10.3354/meps07287

Garcia-Robledo, E., Corzo, A., and Papaspyrou, S. (2014). A fast and direct spectrophotometric method for the sequential determination of nitrate and nitrite at low concentrations in small volumes. Mar. Chem. 162, 30-36. doi: 10.1016/j.marchem.2014.03.002

Garcia-Robledo, E., Corzo, A., Papaspyrou, S., and Morris, E. P. (2012). Photosynthetic activity and community shifts of microphytobenthos covered by green macroalgae. Environ. Microbiol. Rep. 4, 316-325. doi: 10.1111/j.17582229.2012.00335.x

Gómez Ordoñez, E. (2008). Propiedades Ópticas y Teledetección de Macrófitos Marinos en la bahía de Cádiz, España. Cadiz: UniversidaddeCádiz, 23.

Goto, N., Mitamura, O., and Terai, H. (2000). Seasonal variation in primary production of microphytobenthos at the Isshiki intertidal flat in Mikawa Bay. Limnology 1, 133-138. doi: 10.1007/s102010070019

Grant, J. (1986). Sensitivity of benthic community respiration and primary production to changes in temperature and light. Mar. Biol. 90, 299-306. doi: $10.1007 /$ bf00569142

Grasshoff, K., Koroleff, K., and Ehrhardt, M. (1999). Methods of Seawater Analysis. Hoboken, NJ: Wiley Online Library.

Greiner, J. T., Wilkinson, G. M., McGlathery, K. J., and Emery, K. A. (2016). Sources of sediment carbon sequestered in restored seagrass meadows. Mar. Ecol. Prog. Ser. 551, 95-105. doi: 10.3354/meps 11722

Guarini, J.-M., Blanchard, G. F., Bacher, C., Gros, P., Riera, P., Richard, P., et al. (1998). Dynamics of spatial patterns of microphytobenthic biomass: inferences from a geostatistical analysis of two comprehensive surveys in Marennes-Oléron Bay (France). Mar. Ecol. Prog. Ser. 166, 131-141. doi: 10. 3354/meps166131

Guarini, J.-M., Blanchard, G. F., Gros, P., and Harrison, S. J. (1997). Modelling the mud surface temperature on intertidal flats to investigate the spatio-temporal dynamics of the benthic microalgal photosynthetic capacity. Mar. Ecol. Prog. Ser. 153, 25-36. doi: 10.3354/meps153025

Gutiérrez, J. M., Luna del Barco, A., Parrado, J. M., Sánchez, E., Fernández-Palacios, A., and Ojeda, J. (2000). Variaciones de turbidez de las aguas de la bahía de Cádiz determinadas a partir del análisis de imágenes Landsat TM. Geogaceta $27,79-82$.

Hancke, K., and Glud, R. N. (2004). Temperature effects on respiration and photosynthesis in three diatom-dominated benthic communities. Aquat. Microb. Ecol. 37, 265-281. doi: 10.3354/ame037265

Haro, S., Bohórquez, J., Lara, M., Garcia-Robledo, E., González, C. J., Crespo, J. M., et al. (2019). Diel patterns of microphytobenthic primary production in intertidal sediments: the role of photoperiod on the vertical migration circadian rhythm. Sci. Rep. 9, 13376. doi: 10.1038/s41598-01949971-8

Hedges, J. I., Baldock, J. A., Gélinas, Y., Lee, C., Peterson, M. L., and Wakeham, S. G. (2002). The biochemical and elemental compositions of marine plankton: a NMR perspective. Mar. Chem. 78, 47-63. doi: 10.1016/S0304-4203(02)00009-9

Heiri, O., Lotter, A. F., and Lemcke, G. (2001). Loss on ignition as a method for estimating organic and carbonate content in sediments: reproducibility and comparability of results. J. Paleolimnol. 25, 101-110.

Hendriks, I. E., Bouma, T. J., Morris, E. P., and Duarte, C. M. (2010). Effects of seagrasses and algae of the Caulerpa family on hydrodynamics and particletrapping rates. Mar. Biol. 157, 473-481. doi: 10.1007/s00227-009-1333-8

Hijmans, R. J., Williams, E., and Vennes, C. (2017). Package "Geosphere" Spherical Trigonometry for Geographic Applications. Version 1.5-10 Available at: https: //cran.r-project.org/web/packages/geosphere/geosphere.pdf (accessed May 26, 2019).

Hillebrand, H., and Sommer, U. (1999). The nutrient stoichiometry of benthic microalgal growth: Redfield proportions are optimal. Limnol. Oceanogr. 44, 440-446. doi: 10.4319/lo.1999.44.2.0440

Hubas, C., and Davoult, D. (2006). Does seasonal proliferation of Enteromorpha sp. affect the annual benthic metabolism of a small macrotidal estuary? (Roscoff Aber Bay, France). Estuar. Coast. Shelf Sci 70, 287-296. doi: 10.1016/j.ecss.2006. 06.019

Hubas, C., Davoult, D., Cariou, T., and Artigas, L. (2006). Factors controlling benthic metabolism during low tide along a granulometric gradient in an intertidal bay (Roscoff Aber Bay, France). Mar. Ecol. Prog. Ser. 316, 53-68. doi: $10.3354 /$ meps 316053

Jackson, D. A. (1993). Stopping rules in principal components analysis: a comparison of heuristical and statistical approaches. Ecology 74, 2204-2214. doi: $10.2307 / 1939574$

Jesus, B., Brotas, V., Marani, M., and Paterson, D. M. (2005). Spatial dynamics of microphytobenthos determined by PAM fluorescence. Estuar. Coast. Shelf Sci. 65, 30-42. doi: 10.1016/j.ecss.2005.05.005

Jesus, B., Brotas, V., Ribeiro, L., Mendes, C. R., Cartaxana, P., and Paterson, D. M. (2009). Adaptations of microphytobenthos assemblages to sediment type and tidal position. Cont. Shelf Res. 29, 1624-1634. doi: 10.1016/j.csr.2009.05.006

Jimenez-Arias, J. L., Mata, M. P., Corzo, A., Poulton, S. W., März, C., SánchezBellón, A., et al. (2016). A multiproxy study distinguishes environmental change from diagenetic alteration in the recent sedimentary record of the inner Cadiz Bay (SW Spain). Holocene 26, 1355-1370. doi: 10.1177/09596836166 40046

Justić, D., Rabalais, N. N., Turner, R. E., and Dortch, Q. (1995). Changes in nutrient structure of river-dominated coastal waters: stoichiometric nutrient balance and its consequences. Estuar. Coast. Shelf Sci. 40, 339-356. doi: 10.1016/S02727714(05)80014-9

Kagan, B. A., Álvarez, O., Izquierdo, A., Mañanes, R., Tejedor, B., and Tejedor, L. (2003). Weak wind-wave/tide interaction over a moveable bottom: results of numerical experiments in Cadiz Bay. Cont. Shelf Res. 23, 435-456. doi: 10.1016/S0278-4343(02)00223-6

Koh, C. H., Khim, J. S., Araki, H., Yamanishi, H., and Kenichi, K. (2007). Withinday and seasonal patterns of microphytobenthos biomass determined by comeasurement of sediment and water column chlorophylls in the intertidal mudflat of Nanaura. Estuar. Coast. Shelf Sci. 72, 42-52. doi: 10.1016/j.ecss.2006. 10.005

Kühl, M., Glud, R. N., Ploug, H., and Ramsing, N. B. (1996). Microenvironmental control of photosynthesis and photosynthesis-coupled respiration in an epilithic cyanobacterial biofilm. J. Phycol. 32, 799-812. doi: 10.1111/j.00223646.1996.00799.x

Kühl, M., and Jorgensen, B. B. (1994). The light field of microbenthic communities: radiance distribution and microscale optics of sandy coastal sediments. Limnol. Oceanogr. 39, 1368-1398. doi: 10.4319/lo.1994.39.6.1368

Kwon, B.-O., Kim, H. C., Koh, C. H., Ryu, J., Son, S. H., Kim, Y. H., et al. (2018). Development of temperature-based algorithms for the estimation of microphytobenthic primary production in a tidal flat: a case study in Daebu mudflat. Korea. Environ. Pollut. 241, 115-123. doi: 10.1016/j.envpol.2018. 05.032

Kwon, B.-O., Lee, Y., Park, J., Ryu, J., Hong, S., Son, S. H., et al. (2016). Temporal dynamics and spatial heterogeneity of microalgal biomass in recently reclaimed intertidal flats of the Saemangeum area. Korea. J. Sea Res. 116, 1-11. doi: 10.1016/j.seares.2016.08.002

Lara, M., Bohórquez, J., Jimenez-Arias, J. L., Crespo, J. M., Haro, S., Papaspyrou, S., et al. (2018). Microscale drivers of oxygen dynamics during emersion: Microphytobenthic production, sediment compaction and shifts on diffusivity. Eur. Geosci. Union Gen. Assem. Geophys. Res. Abstr. Vol. 20, EGU2018EGU19488.

Lara, M., Bouma, T. J., Peralta, G., Van Soelen, J., and Pérez-Lloréns, J. L. (2016). Hydrodynamic effects of macrophyte microtopography: Spatial consequences of interspecific benthic transitions. Mar. Ecol. Prog. Ser. 561, 123-136. doi: 10.3354/meps11913

Laviale, M., Barnett, A., Ezequiel, J., Lepetit, B., Frankenbach, S., Méléder, V., et al. (2015). Response of intertidal benthic microalgal biofilms to a coupled lighttemperature stress: evidence for latitudinal adaptation along the Atlantic coast 
of Southern Europe. Environ. Microbiol. 17, 3662-3677. doi: 10.1111/14622920.12728

Lee, J.-H., Jeong, K.-S., Lee, D.-H., Park, K. S., and Woo, H. J. (2018). Elemental (C/N Ratios) isotope compositions ( $\delta 13 \mathrm{C}$ TOC and $\delta 15 \mathrm{~N} \mathrm{TN}$ ) of Surface Sediments from the Barrier Islands in the Nakdong River Estuary. South Korea. J. Coast. Res. 85, 36-40. doi: 10.2112/si85-008.1

Lee, Y., Ha, S.-Y., Park, H.-K., Han, M.-S., and Shin, K.-H. (2015). Identification of key factors influencing primary productivity in two river-type reservoirs by using principal component regression analysis. Environ. Monit. Assess. 187, 213. doi: 10.1007/s10661-015-4438-1

Lemley, D. A., Adams, J. B., and Strydom, N. A. (2017). Testing the efficacy of an estuarine eutrophic condition index: does it account for shifts in flow conditions? Ecol. Indic. 74, 357-370. doi: 10.1016/j.ecolind.2016. 11.034

Li, Y.-H., and Gregory, S. (1974). Diffusion of ions in sea water and in deep-sea sediments. Geochim. Cosmochim. Acta 38, 703-714. doi: 10.1016/0016-7037(74) 90145-8

Ligero, R. A., Barrera, M., and Casas-Ruiz, M. (2005). Levels of137Cs in muddy sediments of the seabed of the Bay of Cadiz, Spain. Part I. Vertical and spatial distribution of activities. J. Environ. Radioact. 80, 75-86. doi: 10.1016/j.jenvrad. 2004.05.019

Maggi, E., Rindi, L., Dal Bello, M., Fontanini, D., Capocchi, A., Bongiorni, L., et al. (2017). Spatio-temporal variability in Mediterranean rocky shore microphytobenthos. Mar. Ecol. Prog. Ser. 575, 17-29. doi: 10.3354/meps12216

Méléder, V., Jesus, B., Barnett, A., Barillé, L., and Lavaud, J. (2018). Microphytobenthos primary production estimated by hyperspectral reflectance. PLoS One 13:e0197093. doi: 10.1371/journal.pone.0197093

Migné, A., Spilmont, N., Boucher, G., Denis, L., Hubas, C., Janquin, M.-A., et al. (2009). Annual budget of benthic production in Mont Saint-Michel Bay considering cloudiness, microphytobenthos migration, and variability of respiration rates with tidal conditions. Cont. Shelf Res. 29, 2280-2285. doi: 10.1016/j.csr.2009.09.004

Migné, A., Spilmont, N., and Davoult, D. (2004). In situ measurements of benthic primary production during emersion: seasonal variations and annual production in the Bay of Somme (eastern English Channel, France). Cont. Shelf Res. 24, 1437-1449. doi: 10.1016/j.csr.2004.06.002

Morris, E. P., Peralta, G., Benavente, J., Freitas, R., Rodrigues, A. M., Quintino, V., et al. (2009). Caulerpa prolifera stable isotope ratios reveal anthropogenic nutrients within a tidal lagoon. Mar. Ecol. Prog. Ser. 390, 117-128. doi: 10.3354/ meps08184

Murphy, R. J., Tolhurst, T. J., Chapman, M. G., and Underwood, G. J. C. (2008). Spatial variation of chlorophyll on estuarine mudflats determined by field-based remote sensing. Mar. Ecol. Prog. Ser. 365, 45-55. doi: 10.3354/meps07456

Oakes, J. M., Eyre, B. D., Middelburg, J. J., and Boschker, H. T. S. (2010). Composition, production, and loss of carbohydrates in subtropical shallow subtidal sandy sediments: Rapid processing and long-term retention revealed by13C-labeling. Limnol. Oceanogr. 55, 2126-2138. doi: 10.4319/lo.2010.55.5. 2126

Orvain, F., Lefebvre, S., Montepini, J., Sébire, M., Gangnery, A., and Sylvand, B. (2012). Spatial and temporal interaction between sediment and microphytobenthos in a temperate estuarine macro-intertidal bay. Mar. Ecol. Prog. Ser. 458, 53-68. doi: 10.3354/meps09698

Orvain, F., Sauriau, P.-G., Hir, P., Le Guillou, G., Cann, P., and Paillard, M. (2007). Spatio-temporal variations in intertidal mudflat erodability: Marennes-Oléron Bay, western France. Cont. Shelf Res. 27, 1153-1173. doi: 10.1016/j.csr.2006.05.013

Papaspyrou, S., Diz, P., Garcia-Robledo, E., Corzo, A., and Jimenez-Arias, J. L. (2013). Benthic foraminiferal community changes and their relationship to environmental dynamics in intertidal muddy sediments (Bay of Cadiz, SW Spain). Mar. Ecol. Prog. Ser. 490, 121-135. doi: 10.3354/meps 10447

Peralta, G., van Duren, L., Morris, E., and Bouma, T. (2008). Consequences of shoot density and stiffness for ecosystem engineering by benthic macrophytes in flow dominated areas: a hydrodynamic flume study. Mar. Ecol. Prog. Ser. 368, 103-115. doi: 10.3354/meps07574

Pinckney, J. L., and Zingmark, R. G. (1993). Modeling the annual production of intertidal benthic microalgae in estuarine ecosystems. J. Phycol. 29, 396-407. doi: 10.1111/j.1529-8817.1993.tb00140.x
Pratt, D. R., Pilditch, C. A., Lohrer, A. M., Thrush, S. F., and Kraan, C. (2015). Spatial distributions of grazing activity and microphytobenthos reveal scaledependent relationships across a sedimentary gradient. Estuaries and Coasts 38 , 722-734. doi: 10.1007/s12237-014-9857-7

Revsbech, N. P., Jorgensen, B., and Brix, O. (1981). Primary production of microalgae in sediments measured by oxygen microprofile, $\mathrm{H} 14 \mathrm{CO} 3$ - fixation, and oxygen exchange methods. Limnol. Oceanogr 26, 717-730. doi: 10.4319/lo. 1981.26.4.0717

Revsbech, N. P., and Jorgensen, B. B. (1983). Photosynthesis of benthic microflora measured with high spatial resolution by the oxygen microprofile method: capabilities and limitations of the method. Limnol. Oceanogr. 28, 749-756. doi: 10.4319/lo.1983.28.4.0749

Risgaard-Petersen, N., Dalsgaard, T., Rysgaard, S., Christensen, P. B., Borum, J., McGlathery, K. J., et al. (1998). Nitrogen balance of a temperate eelgrass Zostera marina bed. Mar. Ecol. Prog. Ser. 174, 281-291. doi: 10.3354/meps 174281

Ritchie, R. J. (2008). Universal chlorophyll equations for estimating chlorophylls $\mathrm{a}, \mathrm{b}, \mathrm{c}$, and $\mathrm{d}$ and total chlorophylls in natural assemblages of photosynthetic organisms using acetone, methanol, or ethanol solvents. Photosynthetica 46, 115-126. doi: 10.1007/s11099-008-0019-7

Ruiz-Halpern, S., Vaquer-Sunyer, R., and Duarte, C. M. (2014). Annual benthic metabolism and organic carbon fluxes in a semi-enclosed Mediterranean bay dominated by the macroalgae Caulerpa prolifera. Front. Mar. Sci. 1:67. doi: 10.3389/fmars.2014.00067

Sanchez De Lamadrid Rey, A., and Muñoz Pérez, J. L. (1994). El Medio físico y Biológico en la Bahía de Cádiz: saco Interior. Dirección General de Investigación, Tecnología y Formación Agroalimentaria y Pesquera. Seville: JuntadeAndalucía.

Savelli, R., Dupuy, C., Barillé, L., Lerouxel, A., Guizien, K., Philippe, A., et al. (2018). On biotic and abiotic drivers of the microphytobenthos seasonal cycle in a temperate intertidal mudflat: a modelling study. Biogeosciences 15, 7243-7271. doi: 10.5194/bg-15-7243-2018

Serôdio, J., and Catarino, F. (2000). Modelling the primary productivity of intertidal microphytobenthos: time scales of variability and effects of migratory rhythms. Mar. Ecol. Prog. Ser. 192, 13-30. doi: 10.3354/meps192013

Serôdio, J., Vieira, S., Cruz, S., and Barroso, F. (2005). Short-term variability in the photosynthetic activity of microphytobenthos as detected by measuring rapid light curves using variable fluorescence. Mar. Biol. 146, 903-914. doi: 10.1007/s00227-004-1504-6

Soetaert, K., Petzoldt, T., and Meysman, F. (2010). Marelac: Tools for Aquatic Sciences. $R$ package version 2.1. Available at: https://cran.r-project.org/web/ packages/marelac/vignettes/marelac.pdf (accessed June 03, 2018).

Spilmont, N., Davoult, D., and Migné, A. (2006). Benthic primary production during emersion: in situ measurements and potential primary production in the Seine Estuary (English Channel. France). Mar. Pollut. Bull. 53, 49-55. doi: 10.1016/j.marpolbul.2005.09.016

Stal, L. J., Van Gemerden, H., and Krumbein, W. E. (1984). The simultaneous assay of chlorophyll and bacteriochlorophyll in natural microbial communities. J. Microbiol. Methods 2, 295-306. doi: 10.1016/0167-7012(84)90048-4

Sundbäck, K., Linares, F., Larson, F., Wulff, A., and Engelsen, A. (2004). Benthic nitrogen fluxes along a depth gradient in a microtidal fjord: the role of denitrification and microphytobenthos. Limnol. Oceanogr. 49, 1095-1107. doi: 10.4319/lo.2004.49.4.1095

Tejedor, L., López, A., and Álvarez, O. (1997). Determinación del Nivel Medio del Mar en la Bahía de Cádiz. En: IV Jornadas Españolas de Ingeniería de Costas y Puertos. Spain: Serv. Publicaciones la Univ.

Thamdrup, B., Hansen, J. W., and Jørgensen, B. B. (1998). Temperature dependence of aerobic respiration in a coastal sediment. FEMS Microbiol. Ecol. 25, 189-200. doi: 10.1016/S0168-6496(97)00095-0

Thompson, R. C., Tobin, M. L., Hawkins, S. J., and Norton, T. A. (1999). Problems in extraction and spectrophotometric determination of chlorophyll from epilithic microbial biofilms: towards a standard method. J. Mar. Biol. Assoc. UK 79, 551-558. doi: 10.1017/S0025315498000678

Thornton, D. C. O., Dong, L. F., Underwood, G. J. C., and Nedwell, D. B. (2002). Factors affecting microphytobenthic biomass, species composition and production in the Colne Estuary (UK). Aquat. Microb. Ecol. 27, 285-300. doi: $10.3354 / \mathrm{ame} 027285$

Underwood, G. J. C. (2001). Microphytobenthos. Encycl. Ocean Sci. 3, 807-814. doi: 10.1016/b978-012374473-9.00213-7 
Underwood, G. J. C., and Kromkamp, J. (1999). Primary production by phytoplankton and microphytobenthos in estuaries. Adv. Ecol. Res. 29, 93-153. doi: 10.1016/S0065-2504(08)60192-0

Underwood, G. J. C., and Paterson, D. M. (1993). Seasonal changes in diatom biomass, sediment stability and biogenic stabilization in the severn estuary. J. Mar. Biol. Assoc. United Kingdom 73, 871-887. doi: 10.1017/ S0025315400034780

Van der Wal, D., Herman, P. M. J., Forster, R. M., Ysebaert, T., Rossi, F., Knaeps, E., et al. (2008). Distribution and dynamics of intertidal macrobenthos predicted from remote sensing: Response to microphytobenthos and environment. Mar. Ecol. Prog. Ser. 367, 57-72. doi: 10.3354/meps07535

Van der Wal, D., Wielemaker-van den Dool, A., and Herman, P. M. J. (2010). Spatial synchrony in intertidal benthic algal biomass in temperate coastal and estuarine ecosystems. Ecosystems 13, 338-351. doi: 10.1007/s10021-0109322-9

Walpersdorf, E., Kühl, M., Elberling, B., Andersen, T. J., Hansen, B., Pejrup, M., et al. (2017). In situ oxygen dynamics and carbon turnover in an intertidal sediment (Skallingen. Denmark). Mar. Ecol. Prog. Ser. 566, 49-65. doi: 10.3354/ meps12016
Welker, C., Sdrigotti, E., Covelli, S., and Faganeli, J. (2002). Microphytobenthos in the gulf of trieste (Northern Adriatic Sea): Relationship with labile sedimentary organic matter and nutrients. Estuar. Coast. Shelf Sci. 55, 259-273. doi: 10.1006/ ecss.2001.0901

Zuur, A. F., and Ieno, E. N. (2016). A protocol for conducting and presenting results of regression-type analyses. Methods Ecol. Evol. 7, 636-645. doi: 10.1111/2041210X.12577

Conflict of Interest: The authors declare that the research was conducted in the absence of any commercial or financial relationships that could be construed as a potential conflict of interest.

Copyright (c) 2020 Haro, Lara, Laiz, González, Bohórquez, Garcia-Robledo, Corzo and Papaspyrou. This is an open-access article distributed under the terms of the Creative Commons Attribution License (CC BY). The use, distribution or reproduction in other forums is permitted, provided the original author(s) and the copyright owner(s) are credited and that the original publication in this journal is cited, in accordance with accepted academic practice. No use, distribution or reproduction is permitted which does not comply with these terms. 